\title{
Non-cylindrical parasitic folding and strain partitioning during the Pan-African Lufilian orogeny in the Chambishi-Nkana Basin, Central African Copperbelt
}

\author{
Koen Torremans ${ }^{1, a}$, Philippe Muchez ${ }^{1}$, and Manuel Sintubin ${ }^{1}$ \\ ${ }^{1}$ KU Leuven, Department of Earth and Environmental Sciences, Geodynamics and Geofluids Research Group, \\ Celestijnenlaan 200E, 3001 Leuven, Belgium \\ ${ }^{a}$ present address: Irish Centre for Research in Applied Geosciences, University College Dublin, Dublin 4, Ireland
}

Correspondence: Koen Torremans (koen.torremans@icrag-centre.org)

Received: 31 January 2018 - Discussion started: 6 February 2018

Revised: 3 July 2018 - Accepted: 6 July 2018 - Published: 10 August 2018

\begin{abstract}
A structural analysis has been carried out along the south-east margin of the Chambishi-Nkana Basin in the Central African Copperbelt, hosting the world-class copper and cobalt $(\mathrm{Cu}-\mathrm{Co})$ Nkana orebody. The geometrically complex structural architecture is interpreted to have been generated during a single NE-SW-oriented compressional event, clearly linked to the Pan-African Lufilian orogeny. This progressive deformation resulted primarily in asymmetric multiscale parasitic fold assemblages, characterised by noncylindrical NW-SE-oriented periclinal folds that strongly interfere laterally, leading to fold linkage and bifurcation. The vergence and amplitude of these folds consistently reflect their position along an inclined limb of a NW-plunging megascale first-order fold. A clear relation is observed between the intensity of parasitic folding and the degree of shale content in the Copperbelt Orebody Member (COM), which hosts most of the ore. Differences in fold amplitude, wavelength and shape are explained by changes in mechanical stratigraphy caused by lateral lithofacies variation in orebearing horizons. In addition, strong differences in strain partitioning occur within the deforming basin, which is interpreted to be in part controlled by changes in mechanical anisotropy in the layered rock package. This work provides an essential backdrop to understand the influence of the $\mathrm{Lu}$ filian orogeny on metal mineralisation and (re-)mobilisation in the Copperbelt.
\end{abstract}

\section{Introduction}

The Central African Copperbelt is the largest and highestgrade sediment-hosted copper- and cobalt-producing metallogenic province in the world (Fig. 1). It hosts over 80 deposits with more than 152 million metric tonnes of contained $\mathrm{Cu}$ (Zientek et al., 2010) or approximately 200 million metric tonnes according to Hitzman et al. (2012), as well as the largest Co reserves in the world ( $>60 \%$ ). Metallogenesis in the Central African Copperbelt is generally seen as a multistage and often deposit-specific process with at least some of the following: diagenetic mineralisation pulses are followed by multiple remobilisation stages (including potential new mineralisation) related to basin inversion and compressional deformation, and by later supergene enrichment (e.g. Cailteux et al., 2005; Selley et al., 2005; Dewaele et al., 2006; Haest and Muchez, 2011; Hitzman et al., 2012).

Many unknowns remain regarding the exact nature of compressional deformation in many areas of the Copperbelt, despite the obvious importance with regard to deformation and mobilisation of ore and potential for new input of metals. In the Eastern Middle Lufilian ("Zambian Copperbelt"; Figs. 1 and 2), some of the ore within the deposits is strongly structurally controlled (Brock, 1961; Daly et al., 1984; Selley et al., 2005; Hitzman et al., 2012; Eglinger et al., 2013; Turlin et al., 2016). Ore is for example localised along thrust faultpropagation folds or detachment structures at Nchanga (for location see Fig. 2; McGowan et al., 2003, 2006). At Nkana, ore appears enriched in fold hinges, along tectonic cleavage planes or in several generations of fold-related veins, in 


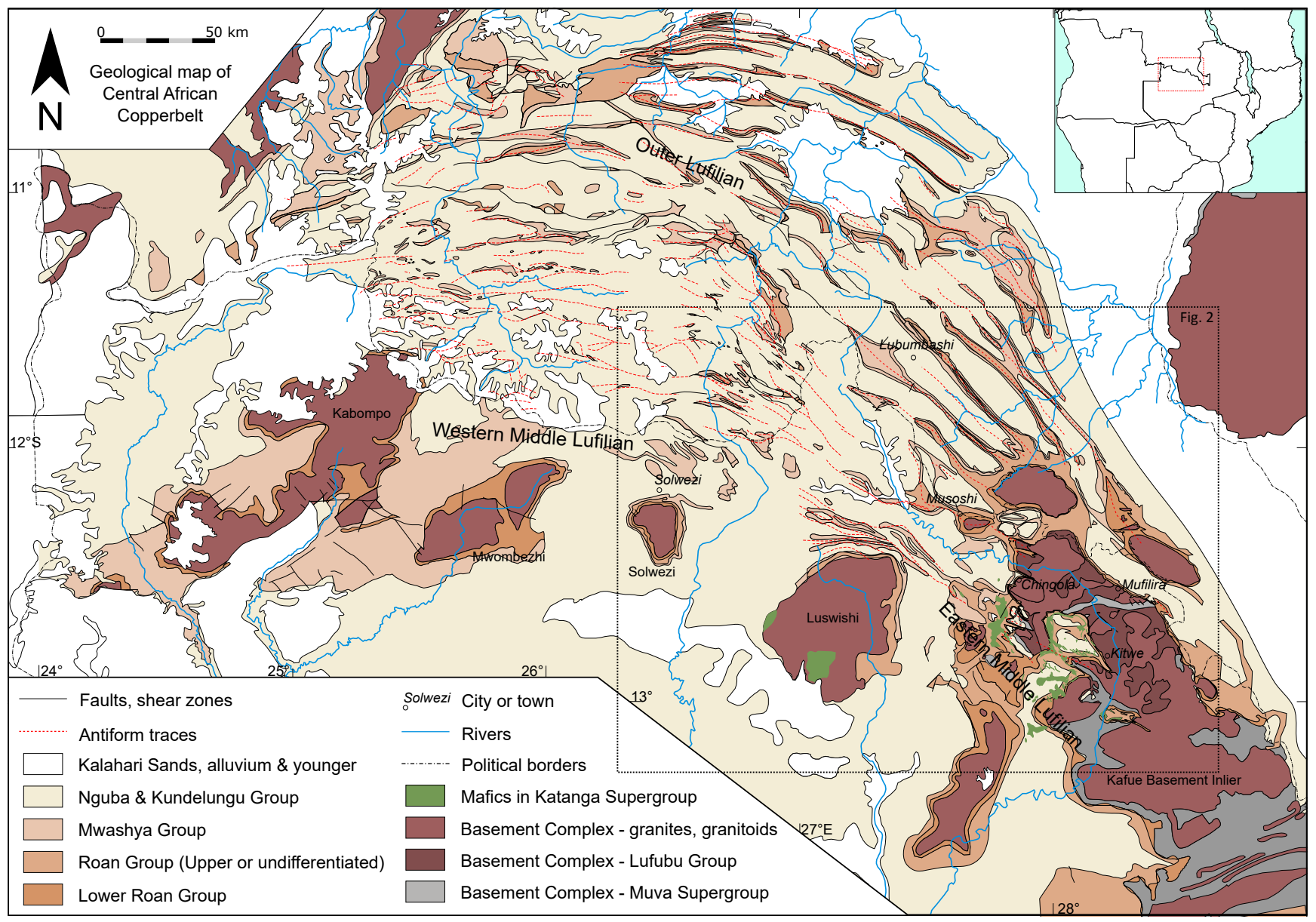

Figure 1. Geological map of the central part of the Central African Copperbelt. Geology is adapted from Thieme and Johnson (1981). Antiform traces are compiled and adapted from Brock (1961), François (1993) and Jackson et al. (2003). Basement subdivision in Kafue basement inlier is based on De Waele et al. (2006). Names of the basement inliers are indicated at their respective locations. Inset shows political borders and position in central Africa.

addition to disseminated and lenticular ore (for location see Fig. 2; Brems et al., 2009; Croaker, 2011; Torremans et al., 2014).

The focus of this study is the Nkana copper and cobalt $(\mathrm{Cu}-\mathrm{Co})$ deposit, one of the world-class $\mathrm{Cu}-\mathrm{Co}$ orebodies in the Eastern Middle Lufilian (Fig. 2). Unequivocal evidence for early diagenetic $\mathrm{Cu}-\mathrm{Co}$ mineralisation is lacking, which does not preclude its existence (Brems et al., 2009; Muchez et al., 2010). At Nkana South, several mineralisation/remobilisation stages have been identified from basin inversion onwards, characterised by different vein generations that formed during compressional deformation (Muchez et al., 2010; Torremans et al., 2014). Geological mapping has indicated that rich orebodies are present in the hinge zones of tight-to-isoclinal folds, both at Nkana South (Brems et al., 2009) and Nkana Central (De Cleyn, 2009). Conversely, at Mindola, the ore occurs in beds that simply dip to the SW without significant folding (for location see Fig. 2; Clara, 2009). A significant lateral variation is hence observed in the way mineralisation occurs in relation to geological structures along the Chambishi-Nkana Basin (Fig. 2; Muchez et al., 2010).

Despite many insights into the metallogenic processes, a detailed structural framework for the Nkana deposit is still lacking. Such a framework is nevertheless paramount for assessing the relation between compressional deformation and mobilisation of the ores and potential input of new ore, and for explaining the lateral variation in the occurrence of the ore at Nkana and similar deposits in one of the great metallogenic provinces of the world. The purpose of this paper is therefore to provide a regional and deposit-scale structural and stratigraphic framework, and to provide general insights into fold-related deformation and the influence of mechanical stratigraphy, in particular with respect to non-cylindrical and parasitic folding and strain partitioning. 


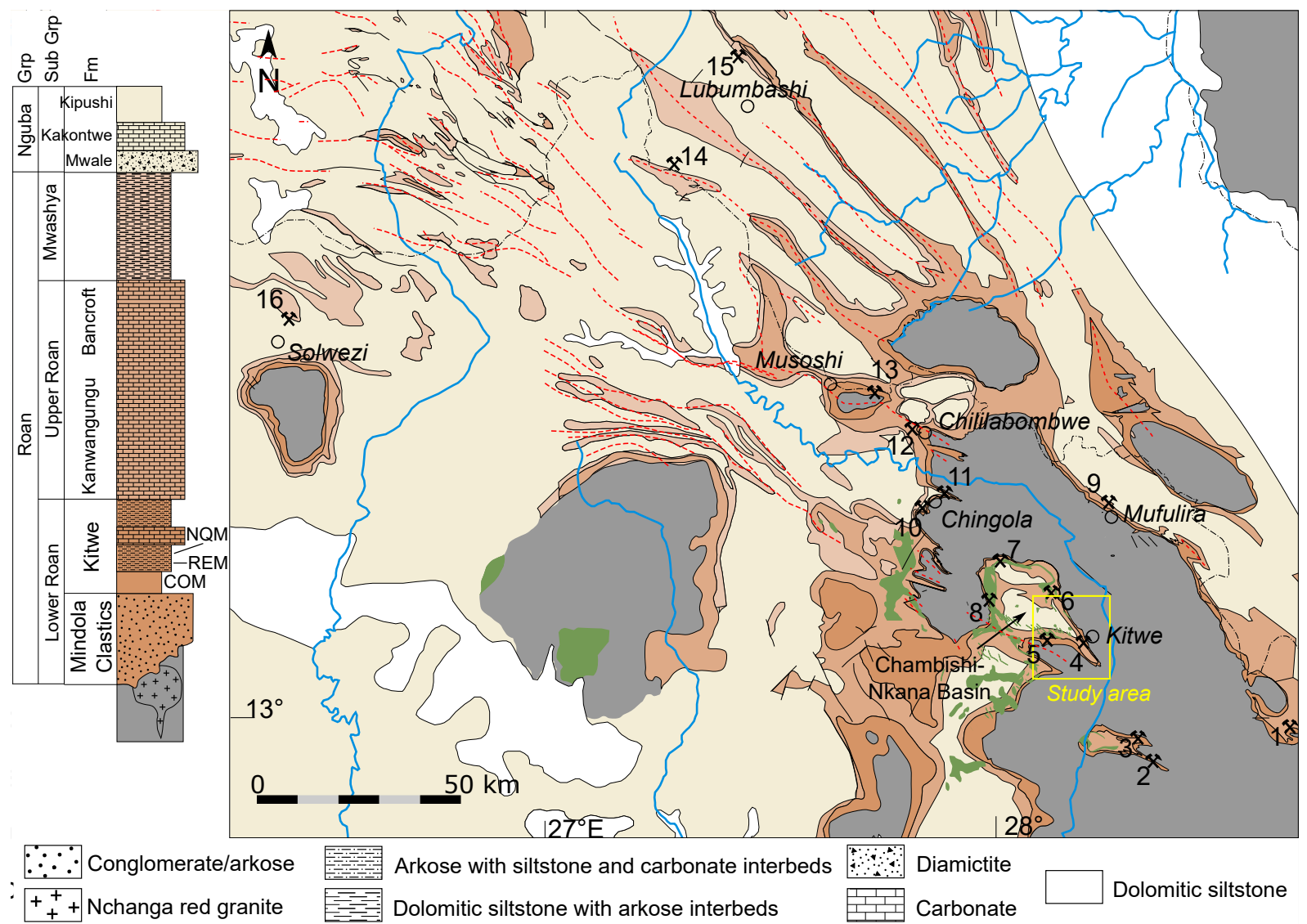

Figure 2. (a) Locations of ore deposits in the Central African Copperbelt that are mentioned in this study. Legend is the same as Fig. 1 except for basement rocks of the Katanga Supergroup that have been combined and are shown in grey. See Fig. 3 for ages of the units. 1: Bwana Mkubwa, 2: Luanshya, 3: Baluba, 4: Nkana South, Nkana Central and Mindola, 5: Chibuluma, 6: Chambishi SE, 7: Chambishi, 8: Mwambashi B, 9: Mufulira, 10: Chingola A-F, 11: Nchanga, 12: Konkola, 13: Musoshi, 14: Kipushi, 15: Luiswishi, 16: Kansanshi. (b) Generalised stratigraphic column of the Katanga Supergroup (excluding Kundelungu Group) and underlying basement rocks (redrawn from Cailteux et al., 1994; Selley et al., 2005; Bull et al., 2011). The predominant lithological characteristics are indicated in symbols. Grp: Group; Sub Grp: Subgroup, Fm: Formation; COM: Copperbelt Orebody Member; NQM: Nchanga Quartzite Member; REM: Rokana Evaporites Member.

\section{Geological and geodynamic setting}

\subsection{Regional geodynamic context}

The geodynamic evolution of the Central African Copperbelt can be roughly subdivided into continental rifting leading to development of the extensional basin, subsequent protooceanic rifting and ultimately inversion and compressional tectonics followed by post-orogenic cooling.

The rocks in the study area belong to the Neoproterozoic to early Cambrian Katanga Supergroup (Figs. 1, 2). Basement rocks of the Katanga Supergroup are exposed in the Kafue basement inlier and smaller surrounding inliers, consisting of the Lufubu and Muva supergroups (Garlick, 1961a; Mendelsohn, 1961; Daly and Unrug, 1982; Johnson et al., 2005; De Waele et al., 2006). The Muva Supergroup quartzites and extensive pre-Katanga granitoids represent positive elements in the current and palaeotopography (Mendelsohn, 1961). The
Katanga Supergroup non-conformably overlies these basement rocks. The basement rocks are intruded by various preKatangan granites. The youngest intrusive body in basement rocks is the A-type Nchanga Red Granite, of which magmatic zircons in quartzite of the Katanga Supergroup were dated at $883 \pm 10 \mathrm{Ma}$ by U-Pb SHRIMP (Armstrong et al., 2005). This age provides a maximum age for sedimentation of the Katanga Supergroup which is further subdivided into the Roan, Nguba and Kundelungu groups (Cailteux et al., 1994).

The lowermost Mindola Clastics Formation (Fm) of the Roan Group contains conglomerates, sandstones and arkoses that were deposited during intracratonic continental rifting in fault-bounded sub-basins (Tembo et al., 1999; Bull et al., 2011). Subsequently, the overlying Copperbelt Orebody Member (COM), often referred to as the Ore Shale and part of the Kitwe Formation, represents the first transgressive sur- 


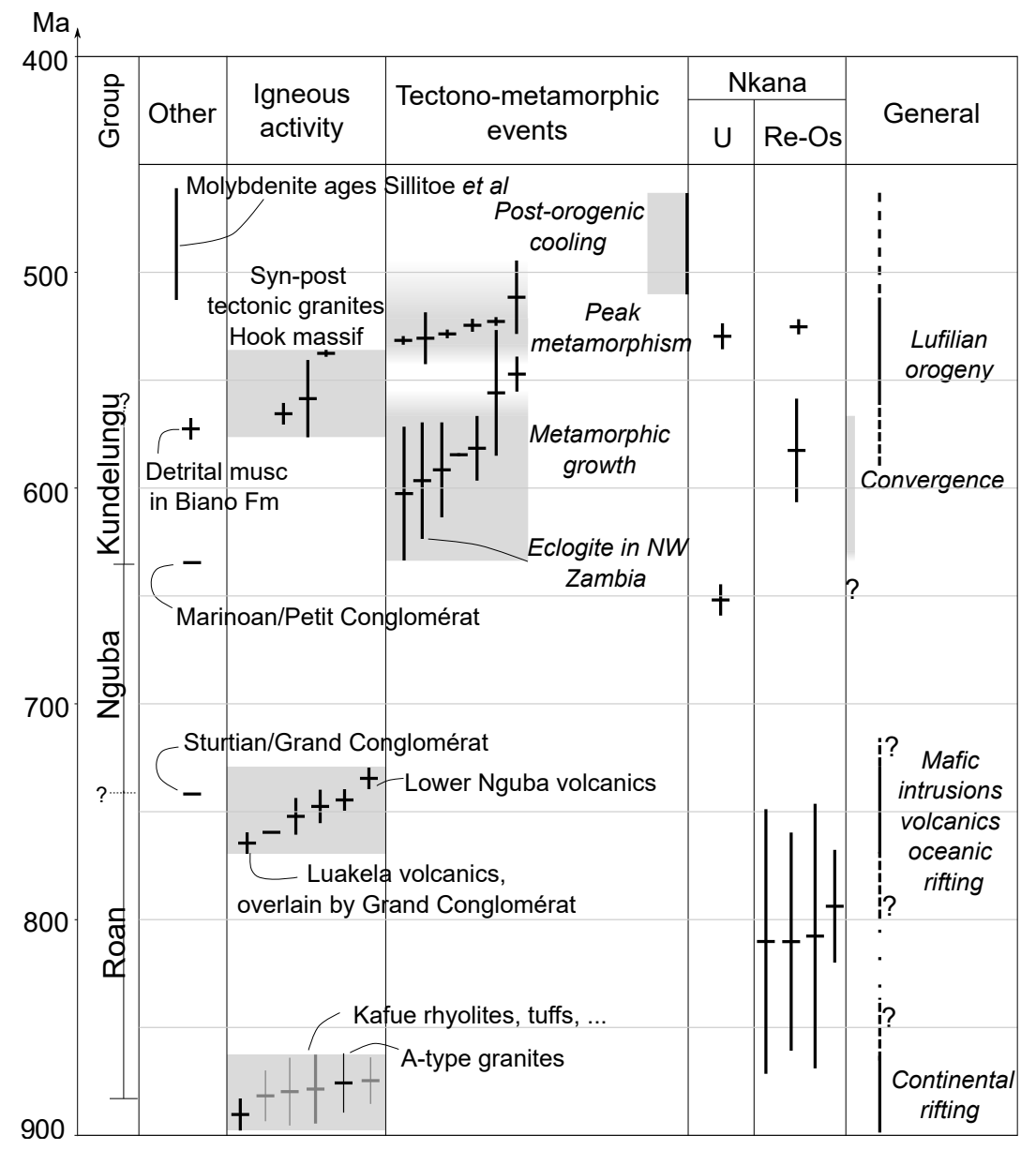

Figure 3. Selected age constraints on tectono-metamorphic events before, during and after deposition of the Katanga Supergroup with interpretation of the major events. Age data are shown with error of $2 \sigma$ and compiled from Barra et al. (2004), Barra (2005), Muchez et al. (2015) and Eastern Zambian Copperbelt data in Sillitoe et al. (2017) for Re-Os dating; Decrée et al. (2011) for U-Pb dating; Cosi et al. (1992), Hanson et al. (1993), Key et al. (2001), Barron et al. (2003), John et al. (2004), Master et al. (2005); Rainaud et al. (2005b), Armstrong et al. (2005) and Johnson et al. (2005) for various igneous and tectono-metamorphic events and Frimmel et al. (2011) for the timing of the Petit and Grand Conglomérat. The base of the Nguba and Kundelungu groups are defined by the base of the Grand Conglomérat and the Petit Conglomérat respectively. An overview of the data and references used in this figure is shown in the Supplement.

face above the red-bed sediments of the Mindola Clastics Formation. The rest of the Kitwe Formation marks rift climax with concomitant fault linkage interpreted as a sag-phase in the rifting (Cailteux et al., 1994; Selley et al., 2005; Batumike et al., 2007; Bull et al., 2011). The evaporate-rich upper Roan Group and Mwashya Group reflect more quiescent conditions in basin development (Cailteux et al., 1994, 2007; Porada and Berhorst 2000; Selley et al., 2005; Bull et al., 2011).

The overlying Nguba and Kundelungu groups contain carbonate and siliciclastic rocks with two regionally extensive basal glaciogenic diamictites (Batumike et al., 2006, 2007). These units reflect continued basin development that lead to proto-oceanic rifting of Afar/Red Sea type (Kampunzu et al.,
1991, 2000; Tembo et al., 1999; Porada and Berhorst, 2000; Key et al., 2001; Batumike et al., 2007). Widespread small gabbroic to dioritic sills and dykes occur in the Katangan $\mathrm{Su}-$ pergroup (Figs. 2, 3), in particular in the Upper Roan and lowermost Nguba groups (Kampunzu et al., 2000). These mafic bodies are constrained between approximately 735 and $765 \mathrm{Ma}$ (Key et al., 2001; Barron et al., 2003), also presenting an approximate age for the extensional tectonics associated with this rifting phase (Buffard, 1988; Tembo et al., 1999; Kampunzu et al., 2000; Batumike et al., 2007).

Inversion from extensional to compressional tectonics during the Pan-African orogeny led to formation of the northward convex Lufilian oroclinal belt (Cosi et al., 1992; Kampunzu and Cailteux, 1999; Porada and Berhorst, 2000). Its 
arcuate shape (Fig. 1) has recently been interpreted as being the result of orogenic bending only after development of the first compressional brittle structures in the orogen (Kipata et al., 2013), although the origin of the bending still remains a matter of discussion (Daly et al., 1984; Kampunzu and Cailteux, 1999; Porada and Berhorst, 2000; Jackson et al., 2003; Selley et al., 2005). Variable deformation styles are observed throughout the arc, both transverse and parallel to the structural grain (Cosi et al., 1992; Jackson et al., 2003; Eglinger et al., 2016; Turlin et al., 2016). Therefore, the Lufilian Arc is often subdivided into different tectonic domains (Fig. 1). Of interest here are the Outer Lufilian ("external fold-andthrust belt"), the Western Middle Lufilian ("Domes region") and the Eastern Middle Lufilian ("Zambian Copperbelt"; De Swardt and Drysdall, 1964; Daly et al., 1984; Jackson et al., 2003; Selley et al., 2005). In the Eastern Middle Lufilian zone, both around and farther north of the Kafue basement inlier, deformation in the Katanga Supergroup is mainly by folding (Porada and Berhorst, 2000; Selley et al., 2005). Only in some localities have shear zones involving both Katanga Supergroup and basement rocks been observed (Coward and Daly, 1984; Daly et al., 1984; McGowan et al., 2006).

The precise timing of tectono-metamorphic events related to basin evolution and the Lufilian orogeny is still underconstrained, in particular in the Eastern Middle Lufilian (Fig. 3). Inversion and deformation of the Katanga Basin occurred during the Lufilian Orogeny starting from 560 to $500 \mathrm{Ma}$ (Hitzman et al., 2012), with the main phase of the orogeny estimated at between 560 and $530 \mathrm{Ma}$ (Selley et al., 2005). The Katanga Supergroup in the study area was metamorphosed to greenschist and lower amphibolite facies, with biotite/phlogopite and tremolite as main metamorphic minerals (Brems et al., 2009). The metamorphic grade and the general lack of datable minerals makes it difficult to directly date tectono-metamorphic events affecting the basinal rocks. A peak-metamorphic $531 \pm 12 \mathrm{Ma} \mathrm{U}-\mathrm{Pb}$ monazite age was obtained by Rainaud et al. (2005a) for the ChambishiNkana Basin in the Eastern Middle Lufilian. Talc-kyanite whiteschists along the contact between basement and Katangan Supergroup rocks record peak metamorphism in the Western Middle Lufilian in NW Zambia (Cosi et al., 1992; Broughton et al., 2002; Eglinger et al., 2016). These highpressure whiteschists are constrained by a $529 \pm 2$ Ma monazite age and $524 \pm 3$ to $532 \pm 2 \mathrm{Ma}$ U-Pb ages (John et al., 2004; Eglinger et al., 2016) and indicate crustal burial, exhumation and thrust stacking of migmatitic basement and Katangan rocks, linked to closure of a southern ocean basin during the Lufilian orogeny (Coward and Daly, 1984; Cosi et al., 1992; Porada and Berhorst, 2000; John et al., 2004). Peak metamorphic ages are therefore quite consistently around 530 to $525 \mathrm{Ma}$ along the entire Middle Lufilian (Fig. 3). Authigenic muscovite and biotite ${ }^{40} \mathrm{Ar}-{ }^{39} \mathrm{Ar}$ and $\mathrm{Rb} / \mathrm{Sr}$ ages of approximately 498 to $465 \mathrm{Ma}$ are interpreted to represent post-orogenic cooling (John et al., 2004; Rainaud et al., 2005a) in agreement with the 510 to $450 \mathrm{Ma} \mathrm{Rb} / \mathrm{Sr}$ muscovite ages from Cosi et al. (1992).

\subsection{The Chambishi-Nkana Basin and Nkana Cu-Co deposit}

The Nkana $\mathrm{Cu}-\mathrm{Co}$ deposit is situated near Kitwe in the Eastern Middle Lufilian (Zambian Copperbelt; Figs. 1, 2). It lies to the west of the Kafue basement inlier, often referred to as the Kafue Anticline (Selley et al., 2005; Hitzman et al., 2012). More specifically, the mine lies on the south-eastern margin of the Chambishi-Nkana Basin which is a synclinorium consisting of a succession of $10^{3}-10^{4} \mathrm{~m}$ amplitude folds, around $40 \mathrm{~km}$ at its widest (Figs. 2, 4). Here, Katanga Supergroup metasediments are surrounded by a variable suite of basement rocks (Bard and Jordaan, 1963). A large-scale SW-verging syncline with a wavelength of approximately $6 \mathrm{~km}$ is developed on the south-east termination of the Chambishi-Nkana Basin (Fig. 4; Bard and Jordaan, 1963; Brems et al., 2009). The study area is situated on the eastern limb of this syncline, which closes to the SE in the Nkana South area.

Nkana is a stratiform deposit in the sense that most of the ore is found near the base of the 10 -to- $20 \mathrm{~m}$ thick COM. Minor ore also occurs at the top of the underlying Mindola Clastics Fm and at the base of hanging wall units overlying it. Mineralisation occurs as disseminated sulfides in the host rock, in several generations of veins and associated with structures such as hinge zones of tight-to-isoclinal folds, deformed veins, faults, and burial or tectonic foliations (Brems et al., 2009; Torremans et al., 2014). Several mineralisation/remobilisation stages have been identified at Nkana (Brems et al., 2009; Muchez et al., 2010). Because of the strong deformation and remobilisation stages, diagenetic mineralisation is often destroyed or replaced, but is generally assumed to be a significant precursor to the current orebody (Brems et al., 2009; Muchez et al., 2010). Current metallogenic models as well as $\mathrm{Pb}, \mathrm{Sr}$ and $\mathrm{Nd}$ isotope data indicate that felsic and mafic basement rocks in the Domes region and the overlying sediments constitute the most likely source area for metals (Carr et al., 1987; Selley et al., 2005; Van Wilderode et al., 2015). The deposit is developed from four shafts: Mindola North, Mindola, Nkana Central and Nkana South. Mining operations at Nkana Central and Nkana South are contiguous for $6.1 \mathrm{~km}$ along strike. To the north, Mindola and Mindola North comprise an additional $6.4 \mathrm{~km}$, separated from Nkana Central by the $1.2 \mathrm{~km}$ Kitwe barren gap and bounded to the north by the Ichimpe barren gap (Fig. 4).

\section{Methodology}

Multiple outcrops were studied $14 \mathrm{~km}$ along strike the southeastern margin of the Chambishi-Nkana syncline (number 1 to 14 in Fig. 4). A list of structural measurements, bore- 


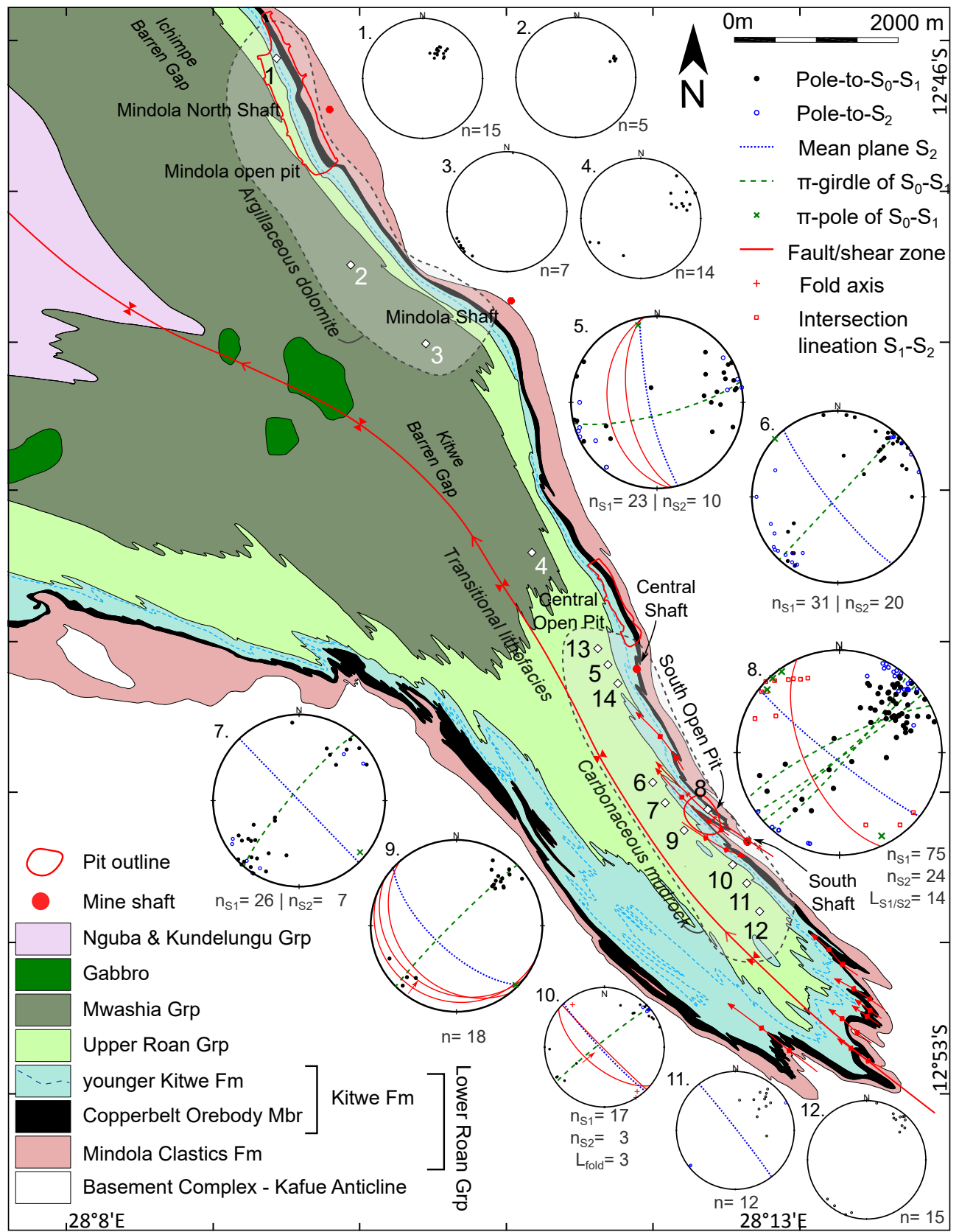

Figure 4. Regional structural analysis and lithological variations in the SE of the Chambishi-Nkana Basin. Geological map with indication of the location of mine shafts and open pits mentioned in this study (modified after Mopani Copper Mines Plc., 2009). The numbers indicate the mine sections that were studied in detail. Also indicated on the map is the spatial distribution of the different lithofacies within the COM. Lower-hemisphere equal-area stereoplots show orientation data in the measured sections. Data and statistics on $S_{1}$ and $S_{2}$ (including $\beta$ girdles and $\pi$ axes) are given in the Supplement.

holes and sections that were used in this study is given with position data in the Supplement. The focus was put on deformation features in the COM and closely adjacent parts of underlying and overlying formations. OpenStereo was used to process some of the structural data (Grohmann and Campanha, 2010). To test for preferred orientations or randomness in the 3-D data, the eigenvalue technique of Woodcock and Naylor (1983) was used. Here, parameters $K$ and $C$ are strength and shape parameters respectively. Low and high $K$ values indicate girdle distributions or clustered data respectively. The strength parameter $C$ indicates the strength of the preferred orientation in the data sample. Values of $K=1$ and $C=0$ are completely randomly distributed. Petrography was performed on polished thin sections, thick doubly polished 


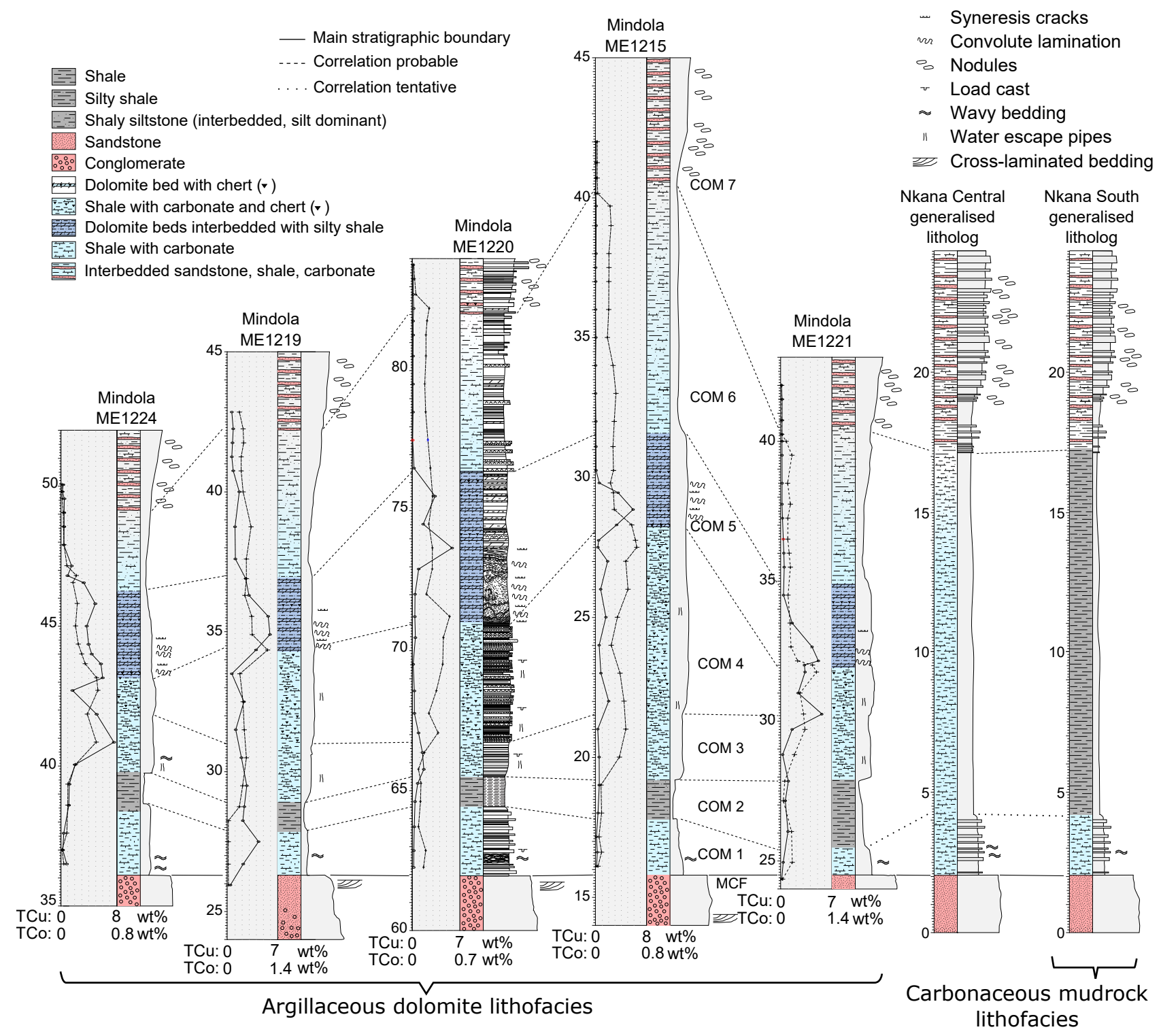

Figure 5. Lithologs of sections at Mindola (typical argillaceous dolomite), Nkana Central and Nkana South (typical carbonaceous mudrock). Log at Mindola is from boreholes, whereas only composite generalised lithologs are shown for Nkana South and Nkana Central because of the deformed nature $\mathrm{COM}$ there. Correlations are based on observed lithological contacts. Total $\mathrm{Cu}$ and $\mathrm{Co}$ values in percent are given in blue and red respectively, reproduced from data provided by Mopani Copper Mines Plc. These analyses were carried out on drill core halves in sections generally 10 to $15 \mathrm{~cm}$ long and averaged over the length of the section. MCF: Mindola Clastics Formation; COM: Copperbelt Orebody Member.

wafers and polished sections. Petrographic and microstructural observations were carried out on 82 thin sections of oriented samples that were obtained in a 2012 field campaign, in addition to 76 thin sections and 35 polished sections available from an extensive sample collection of two previous studies at Nkana (Brems et al., 2009; Muchez et al., 2010).

\section{Lithofacies Variation in the Copperbelt Orebody Member at Nkana (COM)}

The COM is characterised by strong lateral lithofacies variations, resulting in a variable carbonate versus siliciclastic content and grain size (Annels, 1989; Cailteux et al., 1994; Selley et al., 2005; Bull et al., 2011). The term lithofacies is used as a distinct set of mappable units on the mine scale, based on a petrographical study. Four main lithofacies as- 
semblages are recognised in the COM at the Nkana deposit, representing sections through the COM at different localities in the Nkana deposit (Fig. 5). The first-order spatial distribution of the different lithofacies is indicated in Fig. 4. From north to south (Fig. 4) the COM is characterised subsequently by (1) strongly cemented argillaceous dolomites at Mindola, (2) massive dolomites in the Kitwe Barren Gap, (3) turning into a transitional lithofacies north of Nkana Central (also noted by Bard and Jordaan, 1963) and (4) ultimately gradually changing to a carbonaceous mudrock lithofacies with high fissility at Nkana Central and Nkana South. Several patches of transitional lithofacies are present in various areas of Nkana South and Nkana Central.

\subsection{Carbonaceous mudrock lithofacies}

This lithofacies assemblage consists of carbonaceous dark grey-to-black laminated-to-finely bedded pelites and siltstones. A pronounced shaly fabric is often developed, explaining why the mudrocks have been termed "Ore Shale" member or formation in the majority of the literature. Petrographic study shows that the mineralogy consists of quartz, muscovite, biotite, dolomite, K-feldspar (mainly microcline), minor orthoclase, pyrite and chalcopyrite, bornite and pyrrhotite and accessory apatite and zircon (also see Brems et al., 2009; Muchez et al., 2010). Abundant organic matter occurs in the host rock, in the form of disseminated solid bitumen inclusions elongated along shaly cleavage. Total organic carbon contents in whole-rock analyses at Nkana South are between $0.13 \%$ and $3.54 \%$ (Selley et al., 2005; Croaker, 2011). Accessory layers with fine-grained sandstone are found, mainly containing quartz.

\subsection{Argillaceous dolomite lithofacies}

The argillaceous dolomite lithofacies can be subdivided into seven units that are used in the mine as marker horizons (Fig. 5). This lithofacies assemblage consists of laminated-to-thinly bedded argillaceous dolomite with a variable dolomite content. Dolomite content peaks in units 3 and 5 and gradually diminishes stratigraphically upwards. Where dolomite content is low (units 2 and 6), lithologies are pure claystones and siltstones, either laminated-tointerbedded or massive and homogeneous. Dolomite-quartz nodules with pyrite and chalcopyrite occur and are particularly persistent in units 6 and 7, and of minor importance in units 1 and 2. Chicken-wire textures reminiscent of pseudomorphosed gypsum or anhydrite, load casts and dewatering structures occur throughout, most often in units 1,2 and 4. Bedding in units 1,3 and 5 is often wavy and contorted (Fig. 6e, f). The top unit (COM7 on Fig. 5) and transition towards meta-arkoses and quartzites of the Rokana Evaporites Member are similar across the entire deposit, regardless of lithofacies assemblage.

\subsection{Transitional lithofacies}

Laterally, the carbonaceous mudrock lithofacies transitions into a dolomitised siltstone to fine-grained sandstone lithofacies. Generally, this transition is situated $1 \mathrm{~km}$ north of Nkana Central (Fig. 4), however, patches of transitional lithofacies are found in places around Nkana Central (e.g. borehole CE555 in Nkana Central at $100 \mathrm{mN}$ ). The argillaceous dolomite and carbonaceous mudrock are therefore end-member cases of a lithological continuum.

\subsection{Massive dolomite lithofacies}

Other lithofacies associations are recognised at Nkana. The most important is a massive white, occasionally siliceous dolomite, intensely studied by other authors (Bard and Jordaan, 1963; Clemmey, 1974, 1978; Annels, 1989; Croaker, 2011). These studies and others (Selley et al., 2005; Bull et al., 2011) have found that massive dolomite bodies are associated with so-called subeconomic barren gaps in the COM and always lies on inferred basement palaeo-highs. Examples of this are the Kitwe barren gap between Mindola and Nkana Central and the Ichimpe barren gap to the north of Mindola (Fig. 4). In these places, the Mindola Clastics Formation is much thinner to almost non-existent, and transitions towards the lithofacies association at Mindola are very rapid (Jordaan, 1961; Selley et al., 2005). Important alteration by talc, tremolite and anhydrite sometimes affects this dolomite (Porada and Berhorst, 2000; Croaker, 2011; Bull et al., 2011).

\subsection{Gradual change stratigraphically upward towards lithologies that are uniform across the study area}

At all localities a gradual transition is seen towards a more interbedded dark grey calcitic siltstone to fine-grained calcarenite towards the top of the COM (Fig. 5). In addition, at the top, nodules up to $10 \mathrm{~cm}$ in diameter occur in the matrix that reveal strain shadows of dolomite and quartz elongated parallel to local tectonic cleavage. The top of the Mindola Clastics Formation directly beneath the COM occasionally shows dolomitised crossbedding. The lowermost part of the COM generally consists of a strongly altered sequence of variable thickness, named the "Contact Shale".

\section{Structural analysis}

\subsection{Foliations and structural polarity}

A strong, bedding-parallel, shaly cleavage, $S_{1}$, is developed in the carbonaceous mudrock to siltstone lithofacies of the COM (Fig. 6i). In the argillaceous dolomite at Mindola, $S_{1}$ is generally not strongly developed (Fig. 6f). Gradual appearance of this shaly cleavage coincides with the lithofa- 


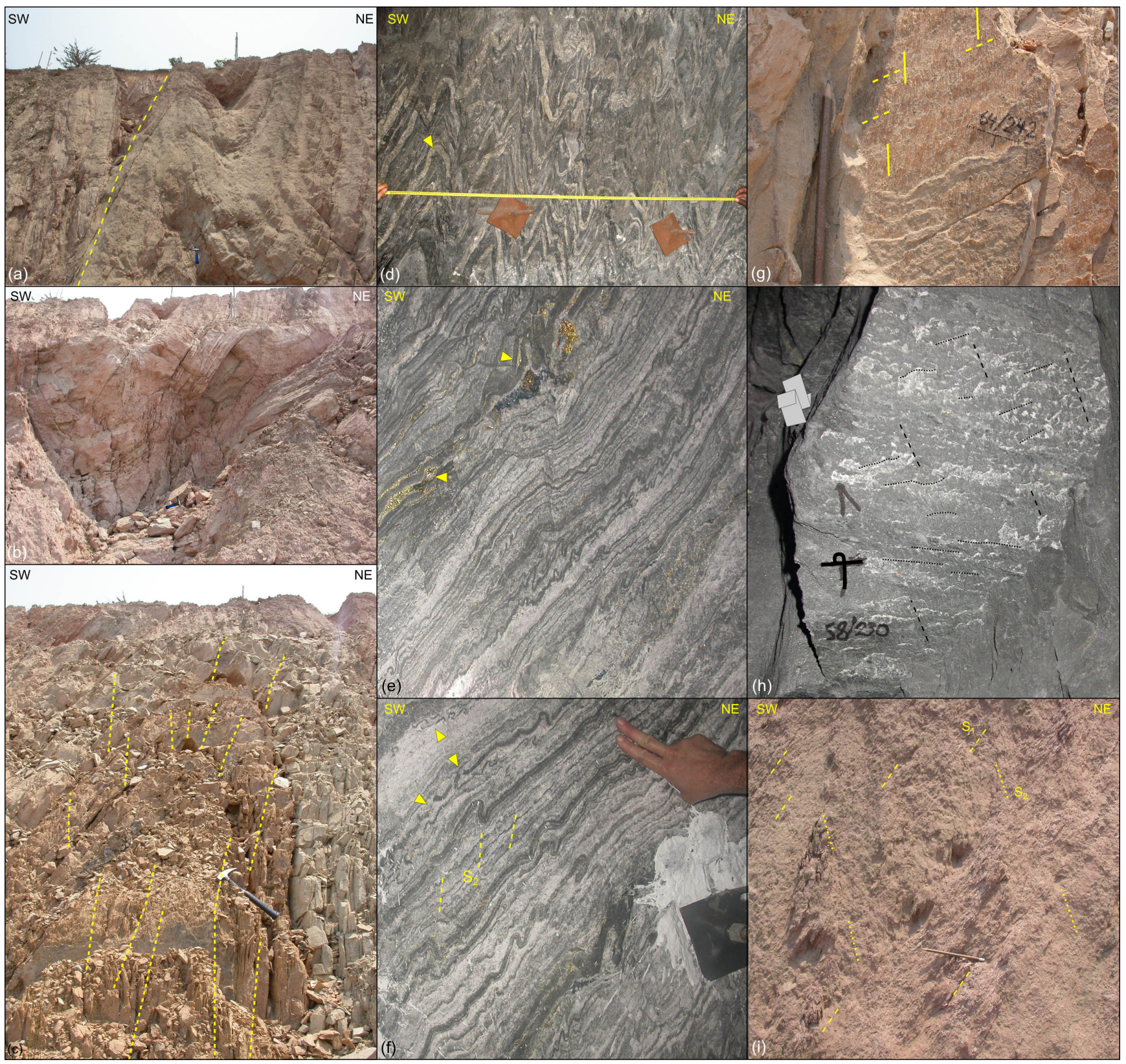

Figure 6. Structural observations at Chambishi-Nkana. See Supplement for detailed locations. (a-c) Third-order folds in the Rokana Evaporites Member. (a) A steep (reverse?) fault developed on the limb of a third-order fold. (b) Third-order parasitic folding in sandstones with a wavelength of around $1 \mathrm{~m}$. (c) Slightly NE-verging anticline. Almost no cleavage refraction can be observed between beds of the Rokana Evaporites Member. (d-f) Fourth-order folding in the COM. (d) High-amplitude folding of bedding-parallel veins in the carbonaceous mudrock lithofacies in section 7. Folds are tight chevron folds, spacing between veins is 2 to $10 \mathrm{~cm}$. (e-f) Intraformational folding of siliciclastic layers (mudstone, siltstone) in dolomite in unit 5 of the argillaceous dolomite at Mindola. The multilayer folding is polyharmonic to disharmonic. The orientation of the tectonic cleavage is subvertical or steeply NW dipping. Chalcopyrite and bornite occur disseminated and in patches. Occasionally, siliciclastic beds are laterally interrupted or broken up (arrows). (g) Dolomite slickenfibres parallel to $S_{1}$ cleavage in the limb of a third-order fold developed in the Rokana Evaporites Member in the Nkana South open pit (section 8). Slickenfibre steps reveal reverse slip and the slickenline lineation (pitch of 80; full lines) is sub-orthogonal to the local $\pi$ axis to $S_{1}$ cleavage plunging $9^{\circ}$ westwards Slickenfibre step lineations (dashed lines) plunge 35 towards 312. (h) Dolomite slickenfibres with steep slickenline lineations (dashed lines) on a $S_{1}$ cleavage plane in the limb of a second-order fold developed in the COM. The pitch of the dolomite slickenfibre steps (dotted lines) is 26 on the overturned $S_{1}$ plane 58/230 in the carbonaceous mudstone in section 6. (i) Carbonaceous mudrock lithofacies of the COM showing a strong bedding-parallel shaly $S_{1}$ foliation. A gentle axial planar tectonic cleavage $S_{2}$ is developed, by discontinuous alignment of micas and sulfides. The rock is therefore an argillite. Pencil for scale. 
cies transition towards carbonaceous mudrock southwards of Nkana Central.

Generally, the tectonic $S_{2}$ cleavage is not as strongly developed as $S_{1}$ in the incompetent layers of the carbonaceous mudrock lithofacies of the COM (Fig. 6i). Here, $S_{2}$ cleavage is developed by the diffuse and discontinuous alignment of micas and sulfides, with occasional $S_{2}$-parallel authigenic dolomite and quartz grains. In the argillaceous dolomite, $S_{2}$ is mainly visible by strong alignment of disseminated micas and sulfides in siliciclastic layers and especially prominent in layers of replacive coarse-grained dolomite.

Locally, a strong disjunctive and anastomosing $S_{2}$ cleavage is developed in the highest strain domains of the carbonaceous mudrock lithofacies at Nkana Central and Nkana South (throughout southern parts of the study area, in outcrops 6, 7, 10 and 12 at Nkana South, but also in outcrop 5 at Nkana Central; Fig. 4). Cleavage spacing is in the order of several centimetres up to 10 or $20 \mathrm{~cm}$ and abundant $\mathrm{Cu}-\mathrm{Co}$ sulfides or micas are aligned along these cleavage planes. The $S_{2}$ cleavage is particularly pronounced when it parallels $S_{1}$, i.e. at 230/90. Often, transposition occurs of ptygmatically folded $S_{1}$-cleavage-parallel veins, showing pinch-and-swell or boudinage parallel to the $S_{2}$ cleavage. Bedding-cleavage $S_{1}-S_{2}$ angular relationships and stratigraphic way-up structures, such as trough crossbedding and scours in the top of the Mindola Clastics Formation show concordant structural and stratigraphic polarity. Antiforms are thus anticlines, synforms synclines. The quartzites and arkoses of the overlying Rokana Evaporates Member and underlying Mindola Clastics Formation do not show significant macroscopic cleavage. The $S_{1}-S_{2}$ intersection lineation (Li) could only be confidently measured in the Nkana South open pit and was difficult to measure in underground crosscuts through the COM.

\subsection{Folds}

\subsubsection{Multiple-order folds along the eastern limb of the Chambishi-Nkana syncline}

The Chambishi-Nkana syncline shallowly plunges to the northwest, showing an undulatory profile with successive axial depressions and culminations (Fig. 4; Jordaan, 1961). It reverses its plunge when approaching the north-western side of the Chambishi-Nkana Basin at the Chambishi and Mwambashi B mines (Fig. 2; Bard and Jordaan, 1963; Selley et al., 2005; Brems et al., 2009). Many $<100 \mathrm{~m}$ scale second-order folds are developed along this first-order fold. The outcrop patterns of these second-order folds show Mtype folds in the south-east and S- or Z-type folds on the south-west and north-east limbs of the first-order syncline respectively (Fig. 4). In turn, the second-order folds are decorated by third-order folds on the scale of several metres, mainly developed in the more competent Rokana Evaporites Member and Nchanga Quartzite Member (Fig. 6a, b). Ultimately, fourth-order folds reveal wavelengths of centimetre to decimetre scales, predominantly developed in the COM (Fig. 7a-d).

In the carbonaceous mudrock lithofacies, pre-folding bedding-parallel fibrous dolomite veins and subsequent overgrowth generations are often strongly buckled and folded or sheared into fourth-order folds (Fig. 6d; Torremans et al., 2014). Certainly in the hinges of second- and third-order folds, these parasitically folded closely spaced veins show high-amplitude M-type folds (Fig. 6d). Conversely, veins of similar spacing in the limbs of second- and third-order folds generally show a smaller amplitude, a strong vergence towards the fold hinge of the lower-order folds and parallelism of fold axial planes with the lower-order folds (Fig. 7a, b).

Many bedding surfaces in the COM and Rokana Evaporites Member show slickensides with mica, chlorite and tremolite fibres and abundant bedding-parallel slickenfibre veins. These slickenlines have a pitch between 70 and $90^{\circ}$ and are orthogonal to local fold hinge lines and $\pi$ axis to $S_{1}$ cleavage (Fig. 6g, h). Lineations formed by the slickenfibre step edges are close to sub-horizontal (max plunge $20^{\circ} \mathrm{NW}$ or SE) and therefore parallel to the local $\pi$ axis to $S_{1}$ cleavage (Fig. 6g, h). At Mindola, dolomite slickenfibre-veins are predominantly present in dolomite-rich coarser-grained units 1,3 and 5 .

Folds at Nkana South (sections 6-12): decametre to hectometre scale second-order folds characterise sections 6 to 12 at Nkana South (Fig. 4). These folds are upright to occasionally overturned with slight NE-verging asymmetry and tightto-isoclinal interlimb angles. Fold trains show wavelengths of approximately $50 \mathrm{~m}$ and a succession of such folds is seen in the Nkana South open pit (section 8 in Figs. 8 and 9) and underground for sections 7 to 9 (Fig. 10d-f). Third-order M-, $\mathrm{S}$ - and Z-type folds are developed on the north-east-verging second-order folds in the Rokana Evaporites Member and the Kafue Arenites Member (section 8; Fig. 6a-c). Occasionally, pinch-and-swell geometries are observed in overturned limbs. At Nkana South and Nkana Central abundant beddingparallel veins show single-layer or disharmonic and polyharmonic multilayer fourth-order folds with wavelengths between 0 and $40 \mathrm{~cm}$ (Fig. 6d).

Foliations in the COM are strongly clustered, reflecting that the COM is often isoclinally folded with high aspect ratios between fold amplitude and wavelength ( $>3$; zones 3 and 4 in Figs. 8b, 9). For example, measured $S_{2}$ values for section 8 are strongly $(C=4.12)$ clustered $(K=2.98)$ with a mean plane at 219/84 (Fig. 8). In addition, poles to $S_{1}$ cleavage are also strongly clustered around 19/038 (Fig. 8). Intense fold hinge thickening is seen in the COM (Fig. 9) leading to class 1C folds (Ramsay, 1967).

Conversely, in the formations overlying the COM poles to $S_{1}$ cleavage of individual folds show great-circle $\beta$-girdle distributions (dashed lines for section 8 in Fig. 8). For the entire fold sequence at the Nkana South open pit, the mean $\beta$ girdles of all combined poles to $S_{1}$ cleavage yield an attitude of $87 / 138$ with a girdle-like distribution, as indicated by a 


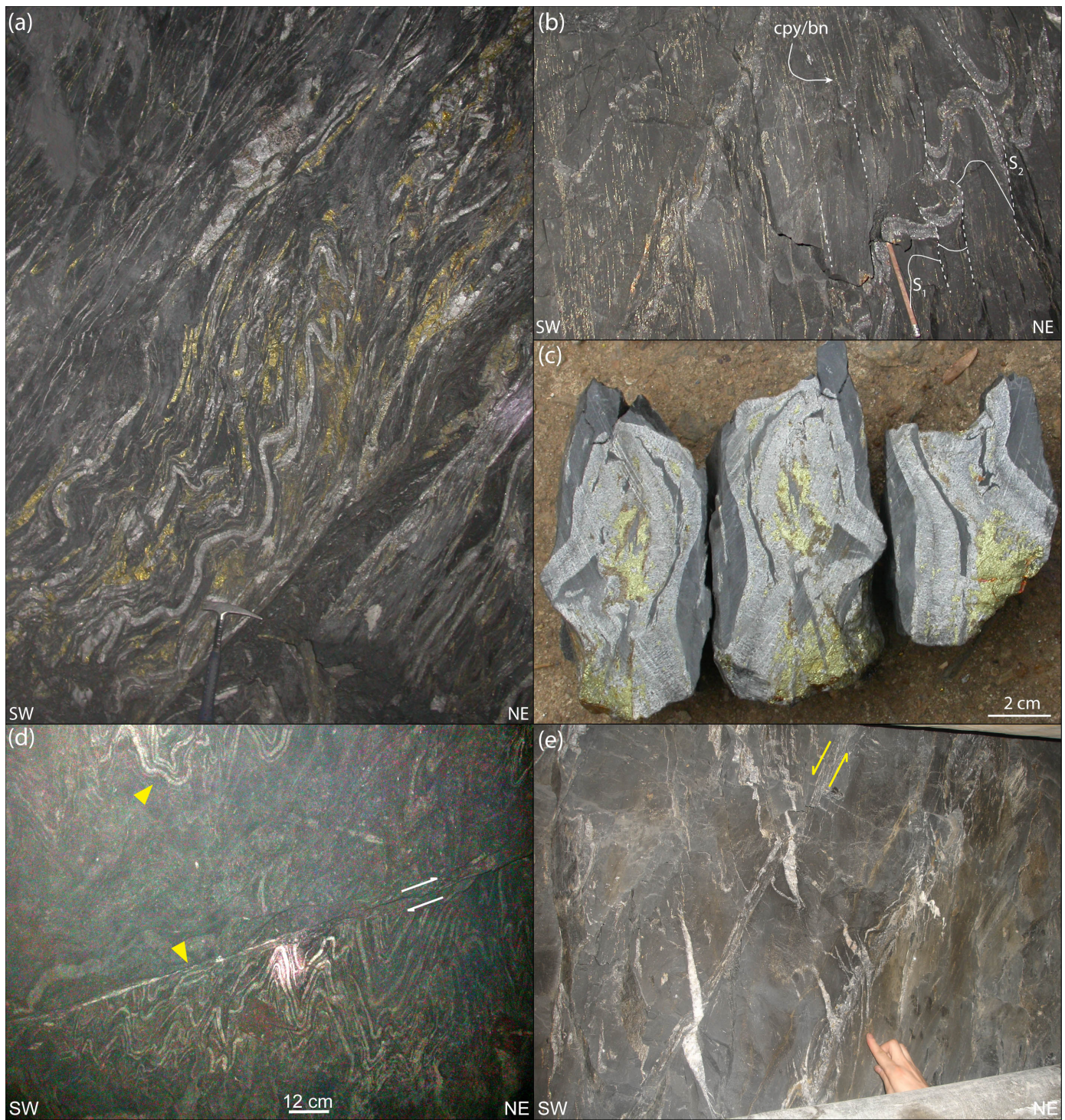

Figure 7. (a) Folded and sheared bedding-parallel veins (type I and II veins of Torremans et al., 2014). Ore mineralisation consists of pyrite, chalcopyrite and bornite in the COM and in syn-folding overgrowths. Section $11 ; 1230 \mathrm{~S} \mathrm{X/C}$. Note distinct difference in amount of sulfides between the densely veined part and the less-veined parts, suggesting that the folding of the closely spaced competent veins provides accommodation problems and transient permeability for deposition of sulfides. (b) Subvertical disjunctive $S_{2}$ cleavage affected folded fibrous bedding-parallel veins. Abundant chalcopyrite, bornite, micas and biotite are found along $S_{2}$. Shear slickenfibres are found along some of the $S_{2}$ planes. Section 6; 910N X/C. (c) Chalcopyrite, bornite and chalcocite in fold hinges of three parallel cuts through a sample of a fourthorder folded fibrous bedding-parallel vein. The axial plane is vertical, at 89/238, with fold limbs oriented 83/238 and 84/058. Section 10; $190 \mathrm{~S}$ X/C. (d) Low-angle reverse fault in $16 \mathrm{~S}$ crosscut (section 9) displacing folded bedding-parallel veins. The fault is orientated $13 / 203$ and mineralised by dolomite and quartz. (e) High-angle normal fault with dolomite arrowhead veins in $473 \mathrm{~N}$ crosscut at section 7 (Fig. 4 ). Slickenlines indicate an almost purely dip slip shear component. This fault is developed in the southern limb of a second-order anticline, with the anticlinal fold hinge towards the right of the photograph. See Supplement for detailed locations.

shape parameter $K$ of 1.29 with a strength $C$ of 2.96 (Woodcock and Naylor, 1983). The pole of this $\beta$-girdle plunges 03/318 (Fig. 8).

The $S_{2}$ cleavage is always axial planar to the folds. Marginal fanning and refraction of $S_{2}$ cleavage is occasionally seen across folds in metapelites in COM unit 7, or in overlying formations although the refraction angle is very small (Fig. 6c). Poles to $S_{2}$ cleavage show slight NE vergence of axial planes, as indicated by the mean $S_{2}$ cleavage plane (84/219) and its pole to mean $S_{2}$ cleavage (06/039). The intersection lineation is quite variably sub-horizontal to gently NW- or SE-plunging. On average, Li plunges 299/08 in section 8 (Figs. 4, 8). 

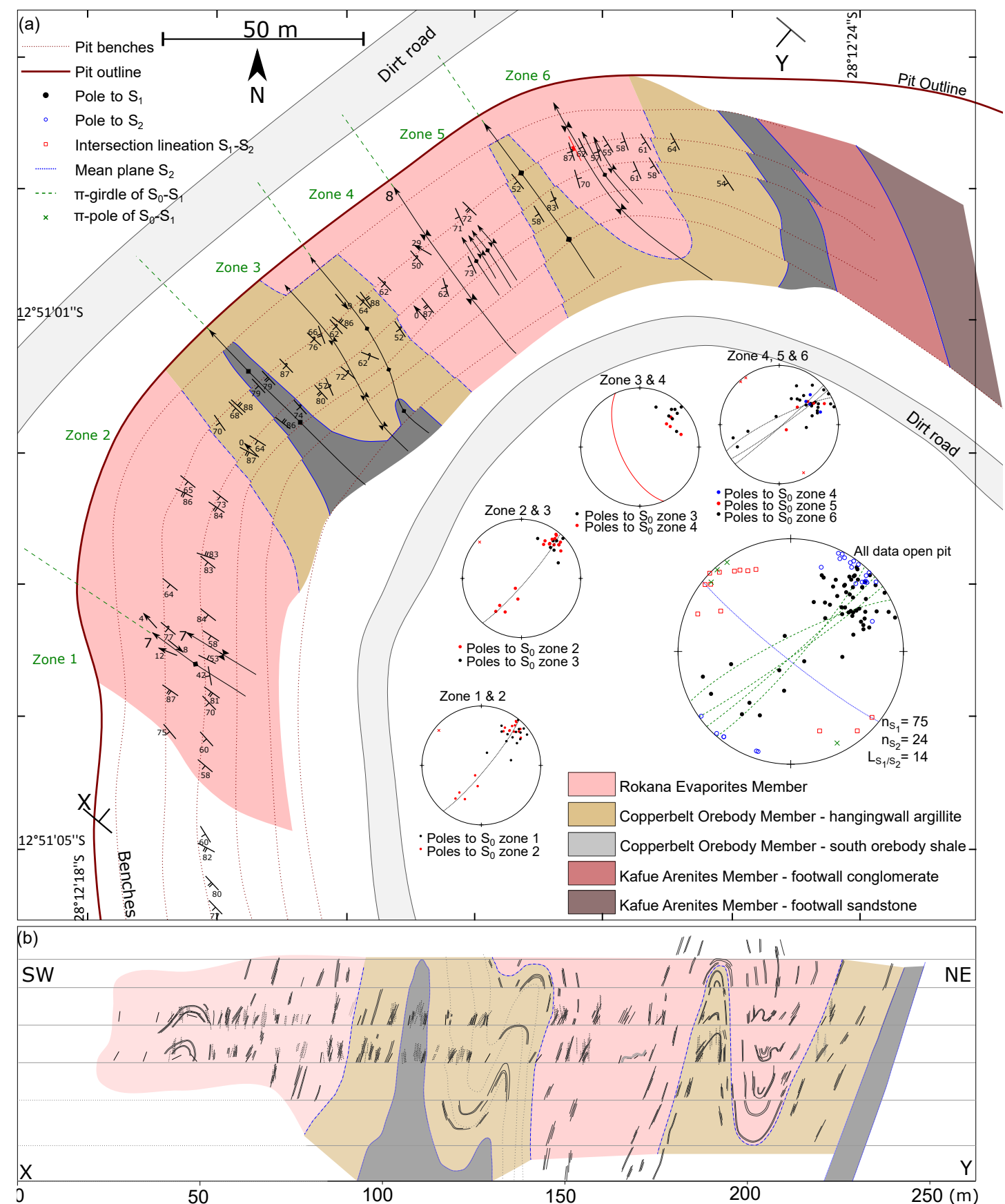

Figure 8. (a) Geological map of the west side of the Nkana South open pit (section 8). Lower-hemisphere equal-area stereoplots refer to particular zones in the pit. Data and statistics on zones, girdles and $\pi$ axes to $S_{1}$ cleavage are given in the Supplement. (b) Cross-section is perpendicular to the structural trend in the open pit and without height exaggeration.

Folds at Nkana Central and Mindola (sections 1-5): second-order folds gradually become more open to the north of Nkana Central shaft and show progressively lower wavelengths and interlimb angles northwards. The lateral spacing between second-order anticlinal fold hinges decreases from less than $100 \mathrm{~m}$ near Nkana South (Figs. 9, 10b) to several hundreds of metres near Nkana Central (Figs. 10c, 11). For example, the second-order folds in outcrops 4 and 5 are developed on a scale of several hectometre. Similarly, the anticline in outcrop 13 shows a moderately open fold developed on the scale of 500-600 m (Fig. 11b). Parasitic fold development on the limbs of second-order folds is also less frequent and at lower amplitudes and wavelengths than at Nkana South. Although folds are more open at Nkana Central, an- 


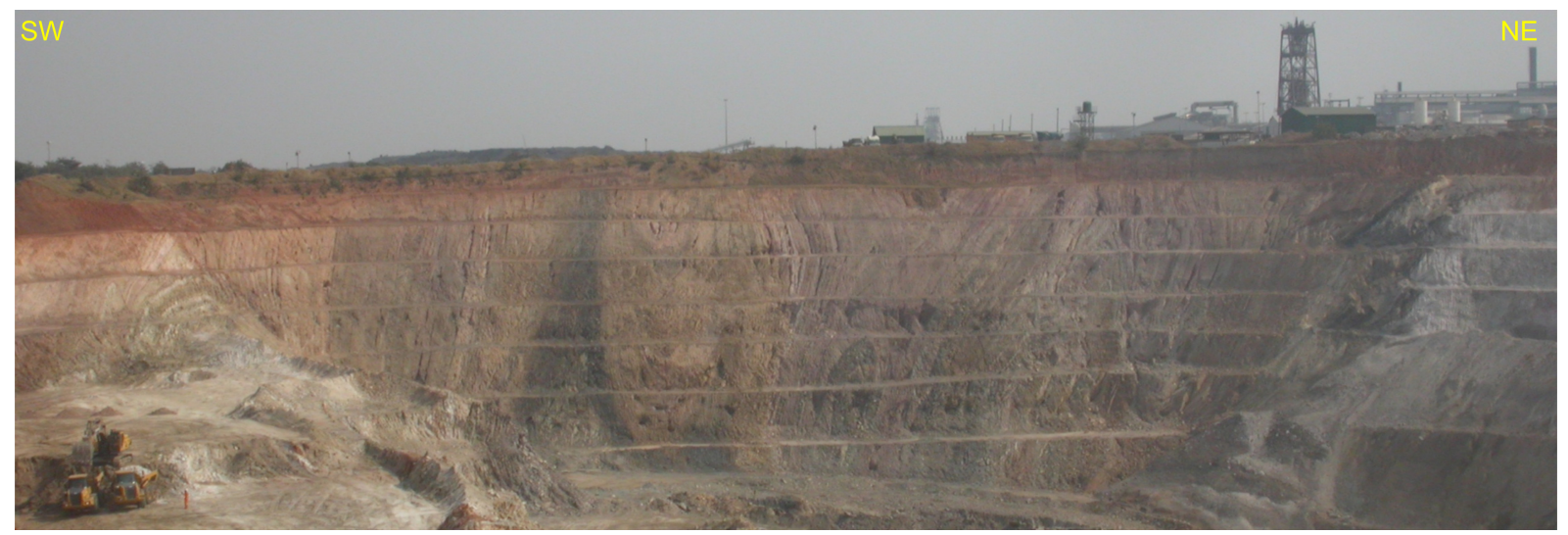

Figure 9. Cross-section view towards the north-west side of the Nkana South open pit, taken 14 August 2012. See Supplement for location where photo was taken. The COM is the black layer, showing isoclinal folding and pinched-out fold hinges. Compare with Fig. $8 \mathrm{~b}$ for geology in cross-section.

gular fold hinges also characterise the COM (Fig. 11b). The strike of the folds is somewhat more north-directed, as indicated by the $\pi$ axis to $S_{1}$ cleavage and the $S_{2}$ cleavage (section 5 in Fig. 4). Folds in section 5 shallowly plunge with the $\pi$ axis to $S_{1}$ cleavage plunging $04 / 348$ and with a fold hinge line plunging 07/345 (Fig. 4).

At the northernmost side of Mindola, beds are broadly warping on the northern normal limb of the first-order syncline, as shown by poles to bedding in Fig. 4. Here, many asymmetrical fourth-order intraformational folds are observed, particularly in units 1, 3 and 5 of the COM (Fig. 6e, f). These folds are mainly developed by the thin silty layers (up to $3 \mathrm{~cm}$ thick) with intermittent dolomite showing considerable thickness variations in between folded siltstone bands. The fold trains show disharmonic to polyharmonic multilayer folding but also change laterally from straight undeformed segments into folded segments (Fig. 6e, f). Many of the siltstone and dolomite bands are also broken up (Fig. 6f). These intraformational folds consistently reveal subvertical to slightly $\mathrm{N}$-verging axial planes clearly expressed by an $S_{2}$ cleavage, along which sulfides are aligned (Fig. 6f).

\subsubsection{Non-cylindrical periclinal fold geometries}

At Nkana South and Nkana Central, second- and third-order folds are non-cylindrical and often doubly plunging. A doubly plunging fold hinge line was directly observed in section view on the SW face of the Nkana South open pit (section 8). Here, the intersection lineation varies between gently NW- and SE-plunging, averaging 299/08, and the total variation in $\mathrm{Li}$ and $\pi$ axes to $S_{1}$ cleavage is approximately $15^{\circ}$ (Fig. 8), which is a similar spread as for the entire Chambishi-Nkana Basin (Fig. 12). Importantly, the abundant third- and fourth-order folds plunge in the same direction as their parent second-order anticline (Fig. 8). Similarly, the $\pi$ axes to $S_{1}$ cleavage plunge both to the NW and SE for several outcrops along the eastern margin of the Chambishi-Nkana Basin (Fig. 4). Doubly plunging folds and undulating fold hinge lines lead to elongate periclinal dome-shaped geometries in geological maps near outcrops 7 and 9 (Fig. 10).

The periclinal fold geometries at Nkana interact along strike, leading to fold linking and bifurcation. The different possible types of fold linkage are shown in Fig. 10a-c. A first example of fold bifurcation occurs at outcrop 13 near Nkana Central (Fig. 6b). Initially, at 1500N, a moderately open second-order fold is developed on the scale of 500 $600 \mathrm{~m}$, with a fold hinge line plunging 07/345. A small thirdorder anticline-syncline pair is developed on the SW limb of this second-order anticline (Fig. 11b). Down plunge, this parasitic fold gains amplitude and wavelength to become a second-order fold plunging approximately $10^{\circ}$ in the same direction. Concomitantly, the northern anticline decreases in size. Ultimately, at $3000 \mathrm{~N}$, the two anticlines are equal in amplitude and wavelength. This structure can therefore be seen as a left lateral bifurcated anticline by lateral linkage of one fold with two other folds (Ghosh and Ramberg, 1968). A second example, at outcrop 14, reveals complex fold patterns in a fold train of parasitic third-order folds along the southwestern limb of a second-order fold (Fig. 11a). This parasitic fold train gradually decreases in importance towards the north-west, dying out on the limbs of the lower-order fold. As a final example, the geological map of $3360 \mathrm{~L}$ mining level at Nkana South published by Brems et al. (2009) shows curved axial traces, elongate periclinal folds and both lateral en echelon linkage and bifurcation fold linkage (vertically below outcrop 8; Fig. 10c). Previous studies at Nkana have identified similar variability in fold hinge lines with plunges between 20 and $40^{\circ}$ north-west and local steepening, flattening and reversing of fold hinge attitudes (Jordaan, 1961; Bard and Jordaan, 1963). Many of the periclinal fold geometries are hence arranged as a left or right lateral en echelon series of folds, showing bifurcation linkage or en echelon link- 


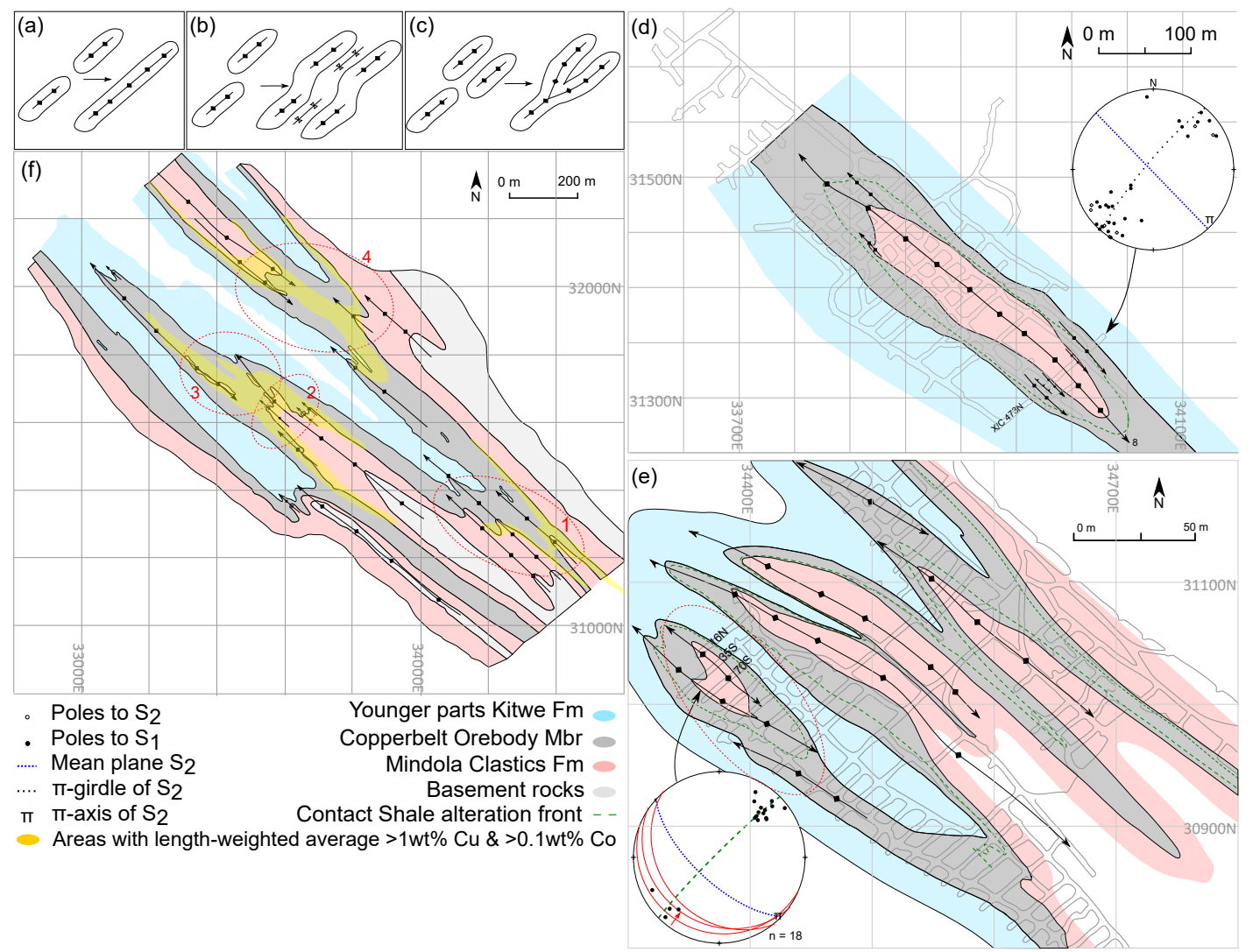

Figure 10. (a-c) Simplified illustration of concepts of fold linkage. (a) Direct fold linkage. (b) En echelon fold linkage. (c) Bifurcation fold linkage. (d-f) Geological plans of underground levels (approximately sub-horizontal) and equal-area lower-hemisphere stereoplots. (d) Geological map of section 7 at 3220 level around 473N crosscut in Nkana South. This section intersects a doubly plunging (periclinal) NW-SE-trending second-order fold geometry. Several third-order parasitic folds are present along the crosscuts. Stereoplot shows measurements in $473 \mathrm{~N}$ crosscut, with the pole to $S_{1}$ cleavage plunging $8^{\circ}$ towards the SE and axial planar $S_{2}$ cleavage. (e) Geological map of section 9 on $3140 \mathrm{~L}$ at Nkana South. The stereoplot shows several shallow-dipping reverse faults trending NW-SE (e.g. Fig. 7d). Folds are tight-to-isoclinally folded and the COM is often pinched out (like in Fig. 9). The folds are arranged in a right-stepping en echelon system and are slightly periclinal. (f) Published geological plan by Brems et al. (2009) of $3360 \mathrm{~L}$ in Nkana South, at around the same position of section 8, slightly towards the NE. Areas in yellow are orebodies as defined by Brems et al. (2009), containing $>1 \mathrm{wt} \% \mathrm{Cu}$ and $0.1 \mathrm{wt} \%$ Co based on length-weighted composite assays from 186 horizontal drill holes. Interpretations of fold axial traces and patterns of geological layer boundaries show several interesting features, indicated by number 1 to 4 . At (1), left-stepping en echelon folds develop. At (2) multiple parasitic folds develop in the Mindola Clastics Fm, where there are also (3) strongly non-cylindrical fold geometries. At (4), a non-cylindrical left-stepping en echelon structure develops, creating a saddle.

age, with frequent asymmetric structural saddles in between second-order folds.

\subsection{Faults and shear zones}

Low-angle reverse faults are recognised in the Mindola Clastics and Kitwe Formations at Nkana South and Nkana Central. Two well-exposed low-angle reverse faults at outcrop 9 reveal $10 \mathrm{~m}$ fault displacements at an angle of $15^{\circ}$, yielding stratigraphic displacements of up to 3 or $4 \mathrm{~m}$ (Fig. 7d). These low-angle faults show laminated veins parallel to the fault surface and cut off folded bedding-parallel veins and disjunctive $S_{2}$ cleavage planes (Fig. 7d). Fault movements are almost pure dip-slip, with a pitch of $85 \mathrm{~S}$ for talc slickenlines on a
$215 / 33$ fault and $87 \mathrm{~S}$ for tremolite slickenlines on a $203 / 13$ fault.

In addition to these low-angle reverse faults, high-angle faults are observed, mostly with normal shear sense and rarely with reverse shear sense. Figure $7 \mathrm{e}$ shows such a steeply dipping fault at outcrop 7, with inferred normal shear sense from several subvertical arrowhead veins with high aspect ratios that straddle the fault surface. The fault is also marked by fault-parallel laminated veins. Similar examples are found in outcrops 8 and 10. Displacements along individual faults are small, on the decimetre to centimetre scale, also for higher levels at the Nkana deposit (Jordaan, 1961; Bard and Jordaan, 1963). 

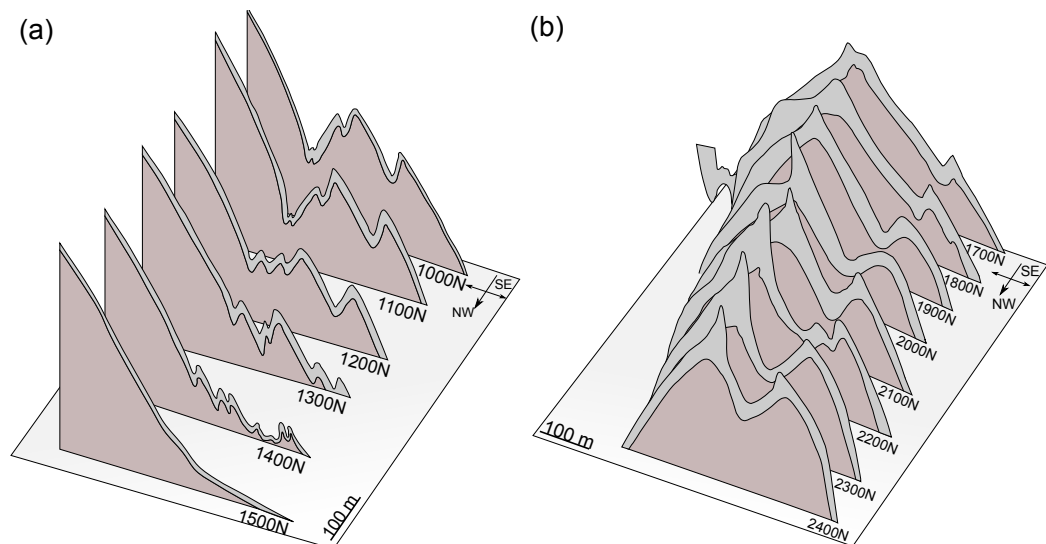

Figure 11. Fence diagrams of cross-sections. View towards the SW of the COM (a) section 13 between 2700 and 3300 level (in feet) and between 1700 and $2400 \mathrm{mN}$ in Nkana Central and (b) section 14 between 2500 and 3300 level (in feet) and between 1000 and $1500 \mathrm{mN}$ in Nkana Central. The diagrams are based on a reconstruction from geological maps, boreholes and subsection plans of Mopani Mines Plc. in the Vulcan software. The COM is shown in grey and various underlying formations are given in red. The plane in light grey represents the horizontal plan of $3300 \mathrm{~L}$ level. (a) The COM is strongly pinched out, and small parasitic folds evolve into major folds from SE to NW as an en echelon fold system. (b) In the NE a strongly developed parasitic second-order fold is seen with multiple third-order folds. This second-order fold gradually dies out towards the NW over a distance of approximately $500 \mathrm{~m}$.
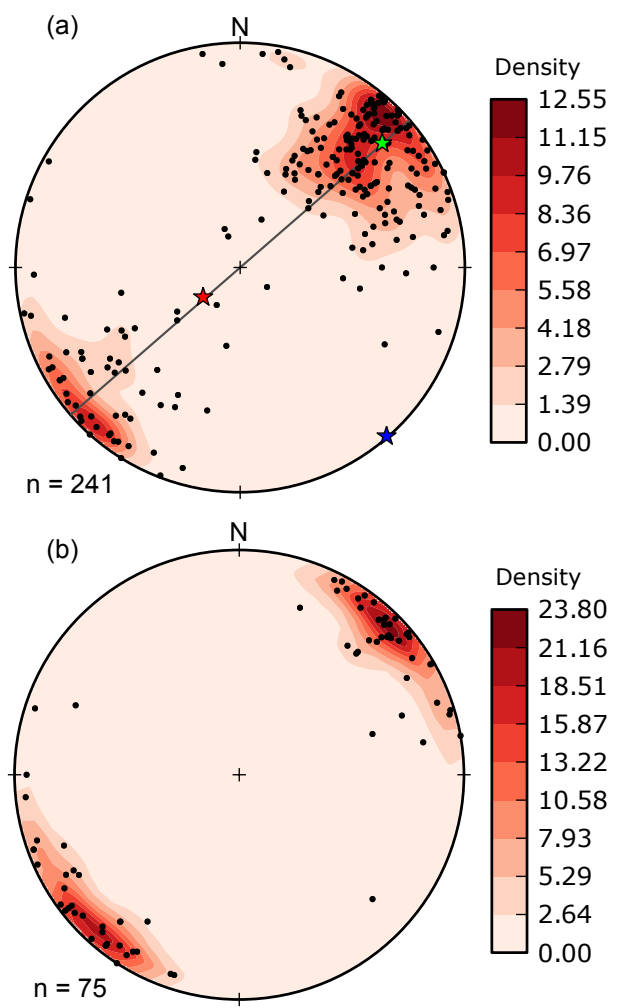

Figure 12. All orientation data at Nkana South, Nkana Central and Mindola. Contouring is done by Fisher distribution. (a) Poles to $S_{1}$ foliation have a maximum density at $047 / 07$. (b) Poles to $S_{2}$ foliation have a maximum eigenvector of the distribution at 043/07.
At Nkana South and Nkana Central, $S_{2}$ cleavage planes in the high-strain areas reveal evidence of shear. In the hinge zones of high-strain chevron folds, steeply inclined shear zones in the COM are found sub-parallel to axial planar $S_{2}$ cleavage.

\subsection{Mineralisation in relation to structural elements}

In the carbonaceous shale, sulfides are generally aligned with $S_{2}$ cleavage, be it as disseminated sulfides elongated parallel to $S_{2}$ or as stringers and layers along more pronounced $S_{2}$ cleavage planes (Fig. 7b). The same is true for sulfides in the host rock of the argillaceous dolomite lithofacies. $\mathrm{Cu}-\mathrm{Co}$ sulfides are more voluminous in fold hinges at different scales. Brems et al. (2009) showed that in Nkana Central and Nkana South, the location of the highest-grade ore bodies generally corresponds to the hinge zones of second- and third-order folds (Fig. 10f). Significant volumes of ore also occur within several generations of veins, syn-kinematic to the folds (Torremans et al., 2014) as well as with volumetrically large veins ( $>10 \mathrm{~cm}$ wide) that are late-kinematic to the folds (Brems et al., 2009; Muchez et al., 2010; Van Wilderode et al., 2015). Low-angle reverse and high-angle normal faults as recognised in our study are not associated with large amounts of sulfides.

\section{Interpretation}

\subsection{Lithofacies variation}

The strong lithofacies variations recognised in the COM in the Chambishi-Nkana Basin are consistent with other stud- 
ies, indicating that sediment deposition in the Mindola Clastics Formation and COM was strongly determined by faultbounded subbasins with half-graben geometries (Garlick, 1961b; Mendelsohn, 1961; Fleischer et al., 1976; Selley et al., 2005). The COM represents the first transgression across this compartmentalised depositional environment (Annels, 1989; Porada and Druschel, 2010; Bull et al., 2011). Later on, more laterally similar conditions developed basin-wide, as evidenced by similarities in Rokana Evaporites and overlying units throughout the Nkana region (see Bull et al., 2011).

\subsection{Development of foliation fabrics}

The $S_{1}$ cleavage is always parallel to bedding and interpreted as a burial compaction cleavage. Development of the tectonic $S_{2}$ cleavage is interpreted as co-genetic with folding, based on the following observations. Throughout the area, $S_{2}$ is always axial planar to the local folds. Moreover, in all crosscuts, the $\pi$ axis to $S_{1}$ cleavage lies on the mean $S_{2}$ plane to within $5^{\circ}$ deviation (Fig. 4). The attitude of Li corresponds quite well to calculated $\pi$ axis to $S_{1}$ cleavage for each of the separate zones in the Nkana South open pit (Fig. 8). Therefore, the variability which is observed in the intersection lineation orientation can be explained by similar variability in the cleavage attitude and by the non-cylindrical nature of the folds.

The strongly clustered sub-vertical mean $S_{2}$ cleavage of $229 / 88$ ( $K=2.51$ and $C=3.05$ ) for all measurements combined ( $n=75$ in Fig. 12) is consistent with the regional SWNE structural grain of the orogen (Kampunzu and Cailteux, 1999; Porada and Berhorst, 2000; Selley et al., 2005). In addition, the combined $\pi$ axis to $S_{1}$ cleavage at Nkana lies very close to the mean $S_{2}$ cleavage plane, at 229/73 (Fig. 12a, b), indicating a slight NE vergence. Moreover, the mean Li attitude of the combined fold train at the Nkana South open pit deviates only slightly from the orientation of the calculated mean fold axis (Fig. 8). Hence, the folding and $S_{2}$ cleavage development are interpreted to have occurred during a single NE-SW-oriented shortening event.

\subsection{Apparent strain gradients and strain partitioning along the eastern limb of the Chambishi-Nkana syncline}

The deformation intensity varies significantly over the extent of the study area: numerous tight, isoclinal folds at Nkana South gradually become more open towards the NW, north of Nkana Central and ultimately show broad warping of relatively undisturbed and steeply inclined beds at Mindola. A general strain gradient is therefore identified from NW to SE. This gradient can be explained by a combination of two factors (Fig. 13).

First and foremost, the gradient is a geometric effect: a transect is made through a NW-dipping megascale parasitic fold train. The first-order syncline dips $20^{\circ} \mathrm{NW}$ and inter-

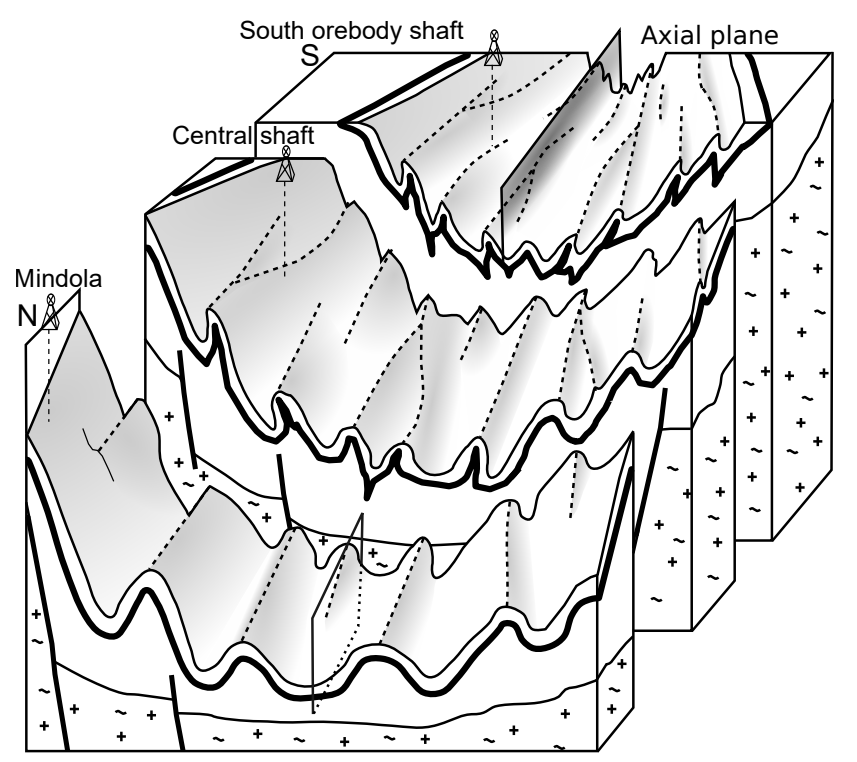

Figure 13. Interpretative schematic block diagram of the SE part of the Chambishi-Nkana Basin, showing first-order synclinal structure plunging $20-30^{\circ}$ to the NW. Only Lower Roan Group stratigraphy is shown with the top of the Lower Roan Group exposed and the COM represented by the thick black line. Third-order folds are tight-to-isoclinally folded in the South generally opening up towards the north. The COM at South Orebody behaves in a ductile way and is pinched out or fault-bounded in the fold hinges, and folds sometimes plunge southwards. Towards the north, the lithofacies of the COM changes to a more competent unit with the Mindola and Mindola North shafts excavating the north-eastern limb of the second-order syncline.

sects a low relief highland topography (Figs. 4 and 13). The hinge zone of this first-order syncline is intersected at Nkana South, showing high-strain, tight-to-isoclinal, highamplitude second- and third-order M-type folds. Parasitic, slightly asymmetric, $\mathrm{S}$ and $\mathrm{Z}$ folds are found laterally on its limbs. The distance between folds increases towards the NW as the topography intersects the first-order fold limb of the Chambishi-Nkana syncline progressively further away from its fold axial plane (Figs. 4 and 13). Ultimately, the Mindola deposit is situated far into the limb of this syncline with widely spaced asymmetric sinusoidal indents in the outcrop pattern of the Upper Roan Group between Nkana Central and Mindola open pit (Figs. 4 and 13).

Secondly, a strong lithofacies variation lies parallel to the strain gradient (see Fig. 4), leading to a change in the macroscale build-up of the multilayer sequence. The COM is characterised by strongly cemented, competent, subtidal to intertidal dolomites at Mindola, but consists of shale or siltstone with high fissility along $S_{1}$ and $S_{2}$ at Nkana Central and Nkana South. Based on the observations in this study, the carbonaceous mudrock takes up much more of the strain during folding compared to the argillaceous dolomite. These observations are therefore an indication of strong strain partition- 
ing in multilayer sequences, caused by lithofacies changes within one unit. Other units in the multilayer sequence do not show such strong lithological variations, except perhaps for large thickness variations in the underlying Mindola Clastics Formation, in relation to palaeogeographic highs (Selley et al., 2005; Croaker, 2011; Bull et al., 2011; Hitzman et al., 2012). Given the lack of direct observations near the axial trace of the first-order fold in the most northern areas (W of Mindola), a discussion point is whether strain intensity in that area is as intense as in the south. If the COM near the axial plane in the northern part of the study area is similar to the argillaceous dolomite at Mindola (broadly expected based on mapping of the lithofacies in Fig. 4), compressive strain would be more evenly distributed across the wholelayer Katanga Supergroup package, and less partitioned into the COM compared to the south (Fig. 13). Small mafic gabbroic to dioritic bodies are regionally widespread and could potentially influence the deformation style locally (Figs. 1, 2 and 4). Unfortunately, we did not encounter mafic bodies in the studied sections, given the sections were in Lower Roan rocks and the mafics occurs predominantly in the Upper Roan and lowermost Nguba Group (Kampunzu et al., 2000).

Analysis of single-layer folded bedding-parallel veins in the carbonaceous mudrock lithofacies of Nkana Central and Nkana South showed that the inferred bulk strain from single-layer folding is over $65 \%$, not taking into account prior layer-parallel shortening (Torremans et al., 2014). Microtextural strain analysis of vein fibres revealed additional post-folding homogeneous shortening of $25 \%$ in the form of cleavage formation during fold lock-up (Torremans et al., 2014).

Locally, in the carbonaceous mudrock lithofacies of the COM at Nkana Central and Nkana South, a significant portioning of the shortening is taken up by cleavage formation. In Mindola, cleavage is not well developed. In the most intensely folded areas (high strain), precipitation of sulfides, quartz, dolomite and mica along disjunctive $S_{2}$ cleavage planes indicates that significant pressure solution and diffusion mass transfer must have taken place. The observation that cleavage formation affects syn-folding veins and the geometrical relation between cleavage and folded veins (Fig. 7b) indicate that development of strong-spaced disjunctive cleavage in the COM is late-kinematic folding in general, at least after fold lock-up (see detailed analysis in Torremans et al., 2014). These observations, combined with the observation that areas of intense cleavage formation coincide with intensely folded and faulted areas, are evidence of progressive strain partitioning towards certain zones of highly intense deformation.

\subsection{Non-cylindricity, interference patterns and strain accommodating mechanisms in folds}

Folds at Nkana reveal non-cylindrical elongate periclinal fold geometries, sometimes arranged en echelon. As there is no evidence for distinct deformation phases, the interference and lateral linking and bifurcation of folds at Nkana is interpreted as linear linkage, en echelon linkage and bifurcation linkage during progressive folding in a single deformation phase (see Fig. 10a-c). These types of fold linkage are mechanically feasible and thought to be a common process during progressive shortening and fold growth (Schmid et al., 2008; Bretis et al., 2011; Grasemann and Schmalholz, 2012). Various forms of fold linkage, the existence of culminations and depressions along fold hinges, and curvature of axial planes in multilayer sequences are all shown to be typical phenomena in single-deformation 3-D fold development, even in plane strains (Muhlhaus et al., 1998; Schmid et al., 2008; Schmalholz and Schmid, 2012; Grasemann and Schmalholz, 2012). Plunge variations, structural saddles and en echelon periclinal geometries (see Fig. 10) all arise from the lateral interactions of growing folds and concomitant angular migration of fold hinges (see Treagus and Treagus, 1981; Lisle et al., 2010; Hudleston and Treagus, 2010).

Abundant evidence for bedding-parallel shear is observed. Slickenfibres on bedding-surfaces are reverse slip in normal limbs of the folds (e.g. Fig. 6g, h) and the slip is highest in the limbs of chevron type folds. The slickenline pitch angles are high and coincide with $\beta$-girdles of bedding. These observations are all indicative of flexural slip folding (Tanner, 1989; Couples et al., 1998). This flexural slip accommodates the second- and third-order tight-to-isoclinal chevron type folding producing strongly pinched-out hinge zones (e.g. Figs. 7c, 8, 9). Conversely, on the fourth-order scale in the carbonaceous mudrock of the COM, microstructures in folded bedding-parallel dolomite veins reveal that the main folding mechanism for the veins was flexural flow. Here, the veins behaved as competent beds in an incompetent matrix characterised by a strong rheological contrast (Torremans et al., 2014). Therefore, within one unit at different scales, multiple folding mechanisms may be active simultaneously.

\subsection{Timing of faulting}

Faults with displacements up to 10 or $20 \mathrm{~m}$ were observed in the deposit (Jordaan, 1961; Bard and Jordaan, 1963; Brems et al., 2009; Croaker, 2011). However, based on our observations, fault displacements at the level of the COM are usually much lower. Low and high-angle normal and reverse faults are generally observed to be late: they postdate folding and development of $S_{2}$, given that faults truncate folded beddingparallel veins (Fig. 7d, e), the relation between faults and $S_{2}$ cleavage and the lack of folded faults. These faults were therefore activated at least after the fold amplification stage of fourth-order folds and during or after late homogeneous 
shortening of folds (see Torremans et al., 2014). We interpret these faults to be related to fold lock-up at high compressional strain. A local NW-SE-trending parallelism exists between fault and fold attitudes. Fault attitudes are parallel to bedding strike across second- and third-order folds, as shown by the coincidence of the $\pi$ axis to $S_{1}$ cleavage and $\mathrm{Li}$ with fault planes for several outcrops (e.g. sections 5 and 9 in Figs. 4, 10b). Although no definitive conclusion can be made on whether these NW-SE-trending faults represent a separate deformation phase or not, this distinct parallelism suggests that folding and later faulting are kinematically linked.

Low-angle reverse faults are consistent with a horizontal NW-SE-oriented $\sigma_{1}$ and NW-SE orogenic shortening. Conversely, late high-angle normal faults show sub-vertical extensional "arrowhead" veins along fault planes. Such vein geometries indicate a horizontal NW-SE $\sigma_{3}$ during a phase where the fault was active and are therefore consistent with a late-tectonic inversion towards an extensional Andersonian regime (Cox et al., 2001; Blenkinsop, 2008).

\section{Discussion}

\subsection{Synthesis and timing of structural events in the SE Chambishi-Nkana Basin}

Basin inversion and compressional deformation are primarily characterised by the development of parasitic fold geometries across 4 orders of scale that form a kinematically coherent system across the length of the south-eastern margin of the Chambishi-Nkana Basin. During this phase of parasitic folding, non-cylindrical periclinal fold geometries developed, caused by along-strike interaction of fold geometries as observed by various types of fold linkage structures. These fold geometries, as well as the development of tectonic cleavage can be explained by a single progressive NE-SW-oriented shortening event. U-Pb SIMS dating of U-bearing minerals at Nkana that were syntectonic to the shortening revealed ages of $530.1 \pm 5.9 \mathrm{Ma}$ (Decrée et al., 2011; Eglinger et al., 2013). In addition, a Re-Os molybdenite age of $525.7 \pm 3.4 \mathrm{Ma}$ was obtained for a sample of a chalcopyrite-bearing vein at Nkana that was late-tectonic to the shortening (Barra, 2005; Selley et al., 2005). This clearly places the NE-SW-oriented shortening event during the Lufilian orogeny. Low-angle reverse faults crosscut already folded geometries and represent late stages of orogeny. High-angle normal faults are interpreted to represent stressstate inversion towards a vertical effective principal stress after compressional tectonic stresses have waned significantly (Van Noten et al., 2011, 2012).

\subsection{Factors influencing fold geometries}

The strong lithofacies changes in the COM from competent argillaceous dolomites to incompetent shales or siltstone change the rheology of the multilayer stratigraphy in differ- ent parts of the Nkana deposit. These lateral changes in the multilayer configuration would have significantly influenced the fold characteristics (Muhlhaus et al., 1998; Fischer and Jackson, 1999; Frehner and Schmalholz, 2006; Tavani et al., 2008; Treagus and Fletcher, 2009). Firstly, the higher fissility and intensity of shaly fabric development at Nkana Central and Nkana South increases the degree of anisotropy in the multilayer sequence, thereby causing more rapid growth of the fold amplitudes (Price and Cosgrove, 1990; Hudleston and Treagus, 2010; Hobbs et al., 2011) compared to folds in the argillaceous dolomite lithofacies. Secondly, the amplitudes of parasitic folds steadily decrease from hinge to inflexion points in the larger-scale folds (see Frehner and Schmalholz, 2006). The highest amplitudes are hence seen near the hinge point of the Chambishi-Nkana syncline at Nkana South, diminishing northwards.

The abundant closely spaced competent bedding-parallel veins in the carbonaceous mudrock lithofacies of the COM experienced extremely high-amplitude folding (Fig. 6d). High numbers of thin competent layers generate higheramplitude amplification rates than sequences with less layers, and they therefore develop higher-amplitude parasitic folds (Frehner and Schmalholz, 2006; Treagus and Fletcher, 2009).

The existence of structural saddles and apparent superposition of two fold trend directions has historically been described as "crossfolding" in the Zambian Copperbelt (Garlick, 1961b; Bard and Jordaan, 1963; Fleischer et al., 1976). More specifically, the NE-SW alignment in culminations and depressions in NW-SE-trending fold hinges was often interpreted as the syntax of early NE and late NW directions of folding, attributed to a D3 Chilatembo deformation phase, either late in or posterior to the Lufilian orogeny (Kampunzu and Cailteux, 1999; Kampunzu et al., 2009; Kipata et al., 2013). These interpretations must be reassessed, considering newly developed insights into the nature of progressive deformation and fold development (Fletcher, 1995; Hudleston and Treagus, 2010; Hobbs and Ord, 2012; Schmalholz and Schmid, 2012) showing that multiple dominant wavelengths and fold hinge line orientations can easily be developed with progressive folding history (Muhlhaus et al., 1998; Schmid et al., 2008; Hobbs et al., 2011; Grasemann and Schmalholz, 2012).

Linking of non-cylindrical periclinal fold geometries is common in deposits with a similar lithostratigraphic architecture throughout the Eastern Zambian Copperbelt, from Konkola in the NW to Luanshya in the SE (See Fig. 2 for locations; Garlick, 1961b; Jordaan, 1961; Schwellnus, 1961; Bard and Jordaan, 1963). At the Chambishi mine, fold hinges attain variable NW or SE plunges in overturned third-order folds that are arranged en echelon on the limb of a SWdipping first-order monoclinal structure (Garlick, 1961b). In Chibuluma, fold hinges plunge $7-10^{\circ}$ towards 330 to 320 (Winfield and Robinson, 1963). Various types of fold linkage can be inferred at Chambishi (e.g. Fig. 93 in Garlick, 1961b). 
In addition, linkage of first-order NW and WNW folds occurs at the Luanshya and Baluba deposits (Mendelsohn, 1961).

\subsection{Strain accommodation during compressional tectonics}

Compressional strain accommodation in the Lower Roan during the Lufilian orogeny at Nkana was mainly via folding on multiple scales, with relatively little accommodation of deformation via faulting. The importance of folding is true for most deposits in the Eastern Zambian Copperbelt (Mendelsohn, 1961; Selley et al., 2005; Hitzman et al., 2012) except perhaps for Nchanga (Fig. 2), where clear detachment faults and fault-propagation folds are seen, strongly influenced by the presence of the Nchanga granite (McGowan et al., 2003, 2006). In several mines of the Eastern Zambian Copperbelt, areas of intense asymmetric and disharmonic folding have been interpreted to be related to thrusting, with folding above a decoupling zone that has significant layer-parallel shearing (e.g. Luanshya, Nchanga and Mufulira; McGowan et al., 2003, 2006; Coward and Daly, 1984; Daly et al., 1984). At Nchanga, sheared granite has indeed been thrust into the Lower Roan (Daly et al., 1984). At Nkana, however, we observed no obvious evidence for a decollement or thrusting near the basement-basin interface in the underground exposures, or higher up the sequence. The non-cylindrical parasitic folding is readily explained by rheology contrasts in the multilayer-cake sedimentary sequence during compression. Since it is clear that both basement and Katanga cover were deformed together in the Lufilian orogeny (Coward and Daly, 1984; Daly et al., 1984), and given these different structural styles, it is likely that both basement-involved thrusting and rheologically controlled folding processes were active together in the Eastern Zambian Copperbelt. Any large-scale tectonic model therefore needs to carefully assess the contribution of either.

Although there is ample evidence for evaporitic conditions in the Chambishi-Nkana Basin, as evident from the lithofacies descriptions (and e.g. Bull et al., 2011), we do not see the effects of salt-driven (detachment) tectonics generating allochthonous pieces of geology. This is in line with other studies in the Eastern Zambian Copperbelt (McCowan et al., 2003; Selley et al., 2005; Torremans et al., 2013), indicating that salt-tectonics, which are hugely important in many parts of the Outer Lufilian in Democratic Republic of the Congo (e.g. Jackson et al., 2003; Hitzman et al., 2012), are much more subdued or absent in the Eastern Zambian Copperbelt.

When comparing the relative orientation of $\mathrm{Li}$ lineations, fold hinge lines, $\pi$ poles to $S_{1}$ cleavage and fault orientation between sections, these structural elements all consistently rotate between sections (Fig. 4). This rotation reflects that of the first-order syncline from $318^{\circ}$ at the SE end of the Basin (e.g. sections 8 and 9; Fig. 4) to approximately $300^{\circ}$ the north-west of Mindola (Fig. 4). The first possible explanation for this covariation and rotation is that this is a natural consequence of 3-D fold growth and linkage, especially since small initial perturbations in palaeo-topography can have a big influence on fold orientation and interaction (Schmid et al., 2008; Bretis et al., 2011; Grasemann and Schmalholz, 2012). A second possibility (not excluding elements of the first) is that inherited extensional basin geometries or basement play a significant role in controlling structure development during later shortening (O'Dea and Lister, 1995; Holdsworth et al., 1997; Bailey et al., 2002; Potma and Betts, 2006).

\section{Conclusions}

The regional structural analysis on the south-east margin of the Chambishi-Nkana Basin has shown that compressional deformation is characterised by parasitic non-cylindrical NW-SE elongate periclinal fold geometries that strongly interfere laterally, leading to fold linking and bifurcation of folds. In the study area, most strain was taken up by asymmetric multiscale parasitic folding and not by fault reactivation, fold-thrusting or detachment faulting. Low- and high-angle reverse faults were observed to be active after the fold amplification stage of fourth-order folds and reflect late stages in the orogenic shortening. High-angle normal faults are consistent with a late-orogenic stress-state inversion (cf. exhumation and orogenic collapse). The geometrically complex compressional structures are interpreted to have been generated during a single NE-SW-oriented shortening event, clearly linked to the Pan-African Lufilian Orogeny. Parasitic fold geometries consistently reflect their position along an inclined NW-plunging megascale fold in the SE of the Chambishi-Nkana Basin. Differences in fold amplitude, wavelength and shape are strongly correlated to lateral lithofacies changes in the ore-bearing horizons, interpreted to reflect the influence of mechanical stratigraphy on folding. In addition, the way strain is partitioned within the deforming basin is in large part controlled by the difference in degree of mechanical anisotropy created by the lithofacies variations within the multilayered rock package. These lateral facies changes are an expression of the depositional environment that was characterised by compartmentalised extensional fault-bounded sub-basins and a strong palaeotopography.

Compressional deformation has enriched the ore body on multiple scales, certainly in the carbonaceous mudrock lithofacies of the COM in Nkana South and Nkana Central. Grades are higher in fold hinges of second- and thirdorder folds, but ore can also be enriched locally, during deformation of competent bedding-parallel veins. In addition, significant volumes of ore occur in several generations of veins that are syn-kinematic to late-kinematic to folding, as well as along tectonic $S_{2}$ cleavage. These observations highlight the potential effects of compressional deformation on ore grades in the fine-grained siliciclastic-hosted $\mathrm{Cu}-\mathrm{Co}$ ore- 
bodies in the Eastern Middle Lufilian. This work provides an essential backdrop to further our understanding of the influence of the Lufilian orogeny on metal mineralisation and (re-)mobilisation in the Central African Copperbelt.

Data availability. The following data are available, in addition to data in the Supplement: lithological descriptions, fieldwork log books, structural measurements and detailed stereoplot analyses, photographs at each of the studied sections, mapping sheets, petrographic descriptions and transmitted and incident light microphotographs, including overview micro-photographs of all thin sections. Photographs of all samples and their structural orientation data are also available. Requests for obtaining these data should be directed to Koen Torremans. A collection of 158 thin sections and 35 polished sections is available. Requests for obtaining these should be directed to Philippe Muchez.

\section{The Supplement related to this article is available online at https://doi.org/10.5194/se-9-1011-2018-supplement.}

Competing interests. The authors declare that they have no conflict of interest.

Acknowledgements. The authors thank Osbert Sikazwe, Willy Nundwe and the School of Mines of the University of Zambia for logistic support. We also thank Mopani Mines Plc. for access to the research area and the geologists at Mopani for logistical assistance and many interesting discussions, in particular Wellington Mukumba, Benny Shikwe, Chanda Luwimba, George Chilufya, Stanley Chasauka, Morden Hangoma, Whiteson Silondwa, Lazarus Mwelwa, Emanuel Mwampokota, Mumba Freda and Kennedy Mpolwa. We are grateful to Jorik Van Wilderode and David Debruyne for assistance during field work and stimulating discussions on the geology, metallogenesis and vein-forming mechanisms at Nkana. We thank two anonymous reviewers for their helpful and constructive reviews and Bernhard Grasemann for editorial handling. We are grateful to Dave Wood and Rob Scott for their critical, constructive and helpful reviews of a previous version of this manuscript. This research was financially supported by research grant OT/11/038 of the KU Leuven Bijzonder Onderzoeksfonds.

Edited by: Bernhard Grasemann

Reviewed by: two anonymous referees

\section{References}

Annels, A. E.: Ore genesis in the Zambian Copperbelt, with particular reference to the Northern Sector of the Chambishi Basin, in: Sediment-hosted stratiform copper deposits, edited by: Boyle, R. W., Brown, A. C., Jeferson, C. W., Jowett, E. C., and Kirkham, R. V., Geological Society of Canada, 427-452, 1989.
Armstrong, R. A., Master, S., and Robb, L. J.: Geochronology of the Nchanga Granite, and constraints on the maximum age of the Katanga Supergroup, Zambian Copperbelt, J. Afr. Earth Sci., 42, 32-40, https://doi.org/10.1016/j.jafrearsci.2005.08.012, 2005.

Bailey, C. M., Giorgis, S., and Coiner, L.: Tectonic inversion and basement buttressing: an example from the central Appalachian Blue Ridge province, J. Struct. Geol., 24, 925-936, https://doi.org/10.1016/S0191-8141(01)00102-X, 2002.

Bard, P. G. and Jordaan, J.: Some structural features associated with the Rokhana orebodies, in: Stratiform Copper Deposits in Africa, 2nd Part: Tectonics, Association of African Geological Surveys, Paris, 179-191, 1963.

Barra, F., Broughton, D., Ruiz, J., and Hitzman, M.: Multi-stage mineralization in the Zambian Copperbelt based on Re-Os constraints, Geological Society of America Denver Annual Meeting, Denver, Colorado, USA, Abstracts with Programs, 36, p. 516, 2004.

Barra, F. L.: Applications of the Re-Os isotopic system in the study of mineral deposits: geochronology and source of metals, $\mathrm{PhD}$ thesis, University of Arizona, USA, 211 pp., 2005.

Barron, J., Broughton, D., Armstrong, R. A., and Hitzman, M.: Petrology, geochemistry and age of gabbroic bodies in the Solwezi area, northwestern Zambia, in: Proterozoic Sedimenthosted Base Metal Deposits of Western Godwana, Contributions Presented at the 3rd IGCP-450 Conference and Guide Book of the Field Workshop, Lubumbashi, 75-77, 2003.

Batumike, M. J., Kampunzu, A. B., and Cailteux, J. H.: Petrology and geochemistry of the Neoproterozoic Nguba and Kundelungu Groups, Katangan Supergroup, southeast Congo: Implications for provenance, paleaweathering and geotectonic setting, J. Afr. Earth Sci., 44, 97-115, 2006.

Batumike, M. J., Cailteux, J. L. H., and Kampunzu, A. B.: Lithostratigraphy, basin development, base metal deposits, and regional correlations of the Neoproterozoic Nguba and Kundelungu rock successions, central African Copperbelt, Gondwana Res., 11, 432-447, https://doi.org/10.1016/j.gr.2006.04.012, 2007.

Blenkinsop, T. G.: Relationships between faults, extension fractures and veins, and stress, J. Struct. Geol., 30, 622-632, 2008.

Brems, D., Muchez, P., Sikazwe, O., and Mukumba, W.: Metallogenesis of the Nkana copper-cobalt South Orebody, Zambia, J. Afr. Earth Sci., 55, 185-196, https://doi.org/10.1016/j.jafrearsci.2009.04.003, 2009.

Bretis, B., Bartl, N., and Grasemann, B.: Lateral fold growth and linkage in the Zagros fold and thrust belt (Kurdistan, NE Iraq), Basin Res., 23, 615-630, https://doi.org/10.1111/j.13652117.2011.00506.x, 2011.

Brock, B. B.: The structural setting of the Copperbelt, in: The geology of the Northern Rhodesian Copperbelt, edited by: Mendelsohn, F., 80-105, MacDonald, London, 1961.

Broughton, D. W., Hitzman, M. W., and Stephens, A. J.: Exploration history and geology of the Kansanshi $\mathrm{Cu}-(\mathrm{Au})$ deposit, Zambia, Soc. Eco. Geo. Spc. Pub., 9, 141-153, 2002.

Buffard, R.: Un rift intracontinental du précambrien supérieur?: le Shaba méridional (Zaïre)?: évolution sédimentaire et tectonique du Supergroupe de Roan au Groupe du Kundelungu inférieur (Supergroupe du Kundelungu), PhD thesis, Université Du Maine, Le Mans, France, 364 pp., 1988.

Bull, S., Selley, D., Broughton, D., Hitzman, M., Cailteux, J., Large, R., and McGoldrick, P.: Sequence and carbon iso- 
topic stratigraphy of the Neoproterozoic Roan Group strata of the Zambian copperbelt, Precambrian Res., 190, 70-89, https://doi.org/10.1016/j.precamres.2011.07.021, 2011.

Cailteux, J., Binda, P. L., Katekesha, W. M., Kampunzu, A. B., Intiomale, M. M., Kapenda, D., Kaunda, C., Ngongo, K., Tshiauka, T., and Wendorff, M.: Lithostratigraphical correlation of the Neoproterozoic Roan Supergroup from Shaba (Zaire) and Zambia, in the central African copper-cobalt metallogenic province, J. Afr. Earth Sci., 19, 265-278, https://doi.org/10.1016/08995362(94)90014-0, 1994.

Cailteux, J. L. H., Kampunzu, A. B., Lerouge, C., Kaputo, A. K., and Milesi, J. P.: Genesis of sediment-hosted stratiform coppercobalt deposits, central African Copperbelt, J. Afr. Earth Sci., 42, 134-158, https://doi.org/10.1016/j.jafrearsci.2005.08.001, 2005.

Cailteux, J. L. H., Kampunzu, A. B., and Lerouge, C.: The Neoproterozoic Mwashya-Kansuki sedimentary rock succession in the central African Copperbelt, its $\mathrm{Cu}-\mathrm{Co}$ mineralisation, and regional correlations, Gondwana Res., 11, 414-431, 2007.

Carr, G. R., Dean, J. A., Korsch, M. J., and Mizon, K. J.: A comparative study of the lead isotopic compositions of mineralization, basement rocks and gabbros from the Copperbelt and "Domes" regions of northern Zambia, Unpublished report, Commonwealth Scientific and Industrial Research Organization, Division of Mineralogy and Geochemistry, Sydney, Australia, 28 pp., 1987.

Clara, E.: Petrographic, mineralogical and geochemical study of the Mindola Cu-Co ore deposit, Zambia, KU Leuven, MSc thesis, KU Leuven, Leuven, Belgium, 102 pp., 2009.

Clemmey, H.: Sedimentary geology of a late Precambrian copper deposit at Kitwe, Zambia, in: Gisements Stratiforme et Provinces Cuprifères, edited by: Bartholomé, P., 255-265, Société Géologique de Belgique, Liège, Belgium, 1974.

Clemmey, H.: A proterozoic lacustrine interlude from the Zambian Copperbelt, in: Modern and Acient Lake Sediments, edited by: Tucker, M. E. and Matter, A., Blackwell scientific publications, Oxford, 259-278, 1978.

Cosi, M., De Bonis, A., Gosso, G., Hunziker, J., Martinotti, G., Moratto, S., Robert, J. P., and Ruhlman, F.: Late Proterozoic thrust tectonics, high-pressure metamorphism and uranium mineralization in the Domes Area, Lufilian Arc, Northwestern Zambia, Precambrian Res., 58, 215-240, https://doi.org/10.1016/0301-9268(92)90120-d, 1992.

Couples, G. D., Lewis, H., and Tanner, P. W. G.: Strain partitioning during flexural-slip folding, Geol. Soc. Spec. Publ., 127, 149165, https://doi.org/10.1144/GSL.SP.1998.127.01.12, 1998.

Coward, M. P. and Daly, M. C.: Crustal lineaments and shear zones in Africa: Their relationship to plate movements, Precambrian Res., 24, 27-45, 1984.

Cox, S. F., Knackstedt, M. A., and Braun, J.: Principles of Structural Control on Permeability and Fluid Flow in Hydrothermal Systems, in: Structural Controls on Ore Genesis, Reviews in Economic Geology 14, edited by: Richards, J. P. and Tosdal, R. M., 1-24, 2001.

Croaker, M. R. D.: Nkana-Mindola sediment-hosted Cu-Co deposit, Zambia, PhD thesis, University of Tasmania, Australia, 363 pp., 2011.

Daly, M. and Unrug, R.: The Muva Supergroup of northern Zambia: a craton to mobile belt sedimentary sequence, Verh. van die Geol. Ver. van Suid-Afrika, 85, 155-165, 1982.
Daly, M. C., Chakraborty, S. K., Kasolo, P., Musiwa, M., Mumba, P., Naidu, B., Namateba, C., Ngambi, O., and Coward, M. P.: The Lufilian arc and Irumide belt of Zambia: results of a geotraverse across their intersection, J. Afr. Earth Sci., 2, 311-318, 1984.

De Cleyn, A.: Petrographic, mineralogical and geochemical study of the Nkana Cu-Co Central Orebody, Zambia, MSc thesis, KU Leuven, Leuven, Belgium, 117 pp., 2009.

Decrée, S., Deloule, É., De Putter, T., Dewaele, S., Mees, F., Yans, J., and Marignac, C.: SIMS U-Pb dating of uranium mineralization in the Katanga Copperbelt: Constraints for the geodynamic context, Ore Geol. Rev., 40, 81-89, https://doi.org/10.1016/j.oregeorev.2011.05.003, 2011.

De Swardt, A. and Drysdall, A.: Precambrian geology and structure in central Northern Rhodesia, Geol. Surv. Zambia Mem., 2, 82 pp., 1964.

De Waele, B., Liégeois, J.-P., Nemchin, A., and Tembo, F.: Isotopic and geochemical evidence of proterozoic episodic crustal reworking within the irumide belt of south-central Africa, the southern metacratonic boundary of an Archaean Bangweulu Craton, Precambrian Res., 148, 225-256, https://doi.org/10.1016/j.precamres.2006.05.006, 2006.

Dewaele, S., Muchez, P., Vets, J., Fernandez-Alonzo, M., and Tack, L.: Multiphase origin of the $\mathrm{Cu}-\mathrm{Co}$ ore deposits in the western part of the Lufilian fold-and-thrust belt, Katanga (Democratic Republic of Congo), J. Afr. Earth Sci., 46, 455-469, https://doi.org/10.1016/j.jafrearsci.2006.08.002, 2006.

Eglinger, A., André-Mayer, A.-S., Vanderhaeghe, O., Mercadier, J., Cuney, M., Decrée, S., Feybesse, J.-L., and Milesi, J.-P.: Geochemical signatures of uranium oxides in the Lufilian belt: From unconformity-related to syn-metamorphic uranium deposits during the Pan-African orogenic cycle, Ore Geol. Rev., 54, 197-213, https://doi.org/10.1016/j.oregeorev.2013.04.003, 2013.

Eglinger, A., Vanderhaeghe, O., André-Mayer, A. S., Goncalves, P., Zeh, A., Durand, C., and Deloule, E.: Tectono-metamorphic evolution of the internal zone of the Pan-African Lufilian orogenic belt (Zambia): Implications for crustal reworking and synorogenic uranium mineralizations, Lithos, 240-243, 167-188, https://doi.org/10.1016/j.lithos.2015.10.021, 2016.

Fischer, M. P. and Jackson, P. B.: Stratigraphic controls on deformation patterns in fault-related folds: A detachment fold example from the Sierra Madre Oriental, northeast Mexico, J. Struct. Geol., 21, 613-633, https://doi.org/10.1016/S01918141(99)00044-9, 1999.

Fleischer, V. D., Garlick, W. G., and Haldane, R.: Geology of the Zambian Copperbelt: Handbook of strata-bound and stratiform ore deposits, edited by: Wolf, K. H., Amsterdam, Elsevier, 506 pp., 1976.

Fletcher, R. C.: Three-dimensional folding and necking of a power-law layer: are folds cylindrical, and, if so, do we understand why?, Tectonophysics, 247, 65-83, https://doi.org/10.1016/0040-1951(95)00021-E, 1995.

Francois, A.: La structure tectonique du katanuien dans la region de Kolwezi (Shaba, Rep. du Zaire), Ann. la Société Géologique Belgique, 116, 87-104, 1993.

Frehner, M. and Schmalholz, S. M.: Numerical simulations of parasitic folding in multilayers, J. Struct. Geol., 28, 1647-1657, https://doi.org/10.1016/j.jsg.2006.05.008, 2006.

Frimmel, H. E., Basei, M. S., and Gaucher, C.: Neoproterozoic geodynamic evolution of SW-Gondwana: a south- 
ern African perspective, Int. J. Earth Sci., 100, 323-354, https://doi.org/10.1007/s00531-010-0571-9, 2011.

Garlick, W. G.: Chambishi, in: The geology of the Northern Rhodesian Copperbelt, edited by: Mendelsohn, F., MacDonald, London, 281-296, 1961a.

Garlick, W. G.: Muva System, in: The geology of the Northern Rhodesian Copperbelt, edited by: Mendelsohn, F., MacDonald, London, 21-29, 1961b.

Ghosh, S. K. and Ramberg, H.: Buckling experiments on intersecting fold patterns, Tectonophysics, 5, 89-105, 1968.

Grasemann, B. and Schmalholz, S. M.: Lateral fold growth and fold linkage, Geology, 40, 1039-1042, https://doi.org/10.1130/G33613.1, 2012.

Grohmann, C. H. and Campanha, G. A.: OpenStereo: Open Source, Cross-Platform Software for Structural Geology Analysis, AGU Fall Meeting, 13-17 December 2010, San Francisco, USA, 2010.

Haest, M. and Muchez, P.: Stratiform and vein-type deposits in the Pan-African Orogen in Central and Southern Africa: evidence for multiphase mineralisation, Geol. Belg., 14, 23-44, 2011.

Hanson, R. E., Wardlaw, M. S., Wilson, T. J., and Mwale, G.: U-Pb zircon ages from the Hook granite massif and Mwembeshi dislocation: constraints on Pan-African deformation, plutonism, and transcurrent shearing in Central Zambia, Precambrian Res., 63, 189-209, https://doi.org/10.1016/0301-9268(93)90033-X, 1993.

Hitzman, M. W., Broughton, D., Selley, D., Woodhead, J., Wood, D., and Bull, S.: The Central African Copperbelt: Diverse Stratigraphic, Structural, and Temporal Settings in the World' $\mathrm{s}$ Largest Sedimentary Copper District, Econ. Geol. Spec. Publ. 16, 487-514, 2012.

Hobbs, B. E. and Ord, A.: Localized and chaotic folding: the role of axial plane structures, Philos. T. Roy. Soc. A, 370, 1966-2009, https://doi.org/10.1098/rsta.2011.0426, 2012.

Hobbs, B. E., Ord, A., and Regenauer-Lieb, K.: The thermodynamics of deformed metamorphic rocks: A review, J. Struct. Geol., 33, 758-818, https://doi.org/10.1016/j.jsg.2011.01.013, 2011.

Holdsworth, R. E., Butler, C. A., and Roberts, A. M.: The recognition of reactivation during continental deformation, J. Geol. Soc. London, 154, 73-78, 1997.

Hudleston, P. J. and Treagus, S. H.: Information from folds: A review, J. Struct. Geol., 32, 2042-2071, https://doi.org/10.1016/j.jsg.2010.08.011, 2010.

Jackson, M. P. A., Warin, O. N., Woad, G. M., and Hudec, M. R.: Neoproterozoic allochthonous salt tectonics during the Lufilian orogeny in the Katangan Copperbelt, Central Africa, Geol. Soc. Am. Bull., 115, 314-330, 2003.

John, T., Schenk, V., Mezger, K., and Tembo, F.: Timing and PT evolution of whiteschist metamorphism in the Lufilian ArcZambezi Belt orogen (Zambia): Implications for the assembly of Gondwana, J. Geol., 112, 71-90, 2004.

Johnson, S. P., Rivers, T., and De Waele, B.: A review of the Mesoproterozoic to early Palaeozoic magmatic and tectonothermal history of south-central Africa: implications for Rodinia and Gondwana, J. Geol. Soc. London, 162, 433-450, 2005.

Jordaan, J.: Nkana, in: The geology of the Northern Rhodesian Copperbelt, edited by: Mendelsohn, F., MacDonald, London, 297328, 1961.

Kampunzu, A. B. and Cailteux, J. L. H.: Tectonic evolution of the Lufilian Arc (Central Africa Copper Belt) during Neoproterozoic Pan African orogenesis, Gondwana Res., 2, 401-421, 1999.
Kampunzu, A. B., Kapenda, D., and Manteka, B.: Basic magmatism and geotectonic evolution of the Pan African belt in central Africa: Evidence from the Katangan and West Congolian segments, Tectonophysics, 190, 363-371, 1991.

Kampunzu, A. B., Tembo, F., Matheis, G., Kapenda, D., and Huntsman-Mapila, P.: Geochemistry and tectonic setting of mafic igneous units in the Neoproterozoic Katangan Basin, Central Africa: implications for Rodinia break-up, Gondwana Res., 3, 125-153, https://doi.org/10.1016/s1342-937x(05)700939, 2000.

Kampunzu, A. B., Cailteux, J. L. H., Kamona, A. F., Intiomale, M. M., and Melcher, F.: Sediment-hosted $\mathrm{Zn}-\mathrm{Pb}-\mathrm{Cu}$ deposits in the Central African Copperbelt, Ore Geol. Rev., 35, 263-297, https://doi.org/10.1016/j.oregeorev.2009.02.003, 2009.

Key, R. M., Liyungu, A. K., Njamu, F. M., Somwe, V., Banda, J., Mosley, P. N., and Armstrong, R. A.: The western arm of the Lufilian Arc in NW Zambia and its potential for copper mineralization, J. Afr. Earth Sci., 33, 503-528, https://doi.org/10.1016/S0899-5362(01)00098-7, 2001.

Kipata, L. M., Delvaux, D., Sebagenzi, M. N., Cailteux, J., and Sintubin, M.: Pan-African Lufilian arc and its foreland (Katanga, DRC): from orogenic compression to extensional collapse, transpressional inversion and transition to rifting, Geol. Belg., 16, 1$17,2013$.

Lisle, R. J., Toimil, N., Aller, J., Bobillo-Ares, N., and Bastida, F.: The hinge lines of non-cylindrical folds, J. Struct. Geol., 32, 166171, https://doi.org/10.1016/j.jsg.2009.10.011, 2010.

Master, S., Rainaud, C., Armstrong, R. A., Phillips, D., and Robb, L. J.: Provenance ages of the Neoproterozoic Katanga Supergroup (Central African Copperbelt), with implications for basin evolution, J. Afr. Earth Sci., 42, 41-60, 2005.

McGowan, R. R., Roberts, S., Foster, R. P., Boyce, A. J., and Coller, D.: Origin of the copper-cobalt deposits of the Zambian Copperbelt: An epigenetic view from Nchanga, Geology, 31, 497-500, 2003.

McGowan, R. R., Roberts, S., and Boyce, A. J.: Origin of the Nchanga copper-cobalt deposits of the Zambian Copperbelt, Miner. Deposita, 40, 617-638, https://doi.org/10.1007/s00126005-0032-8, 2006.

Mendelsohn, F.: The Geology of the Northern Rhodesian Copperbelt, MacDonald, London, 523 pp., 1961.

Muchez, P., El Desouky, H., Brems, D., De Cleyn, A., Lammens, L., Cailteux, J., Boyce, A., De Muynck, D., Mukumba, W., and Sikazwe, O.: Evolution of $\mathrm{Cu}-\mathrm{Co}$ mineralizing fluids at Nkana Mine, Central African Copperbelt, Zambia, J. Afr. Earth Sci., 58, 457-474, https://doi.org/10.1016/j.jafrearsci.2010.05.003, 2010.

Muchez, P., André-Mayer, A.-S., El Desouky, H. A., and Reisberg, L.: Diagenetic origin of the stratiform $\mathrm{Cu}-\mathrm{Co}$ deposit at Kamoto in the Central African Copperbelt, Miner. Deposita, 50, 437-447, https://doi.org/10.1007/s00126-015-0582-3, 2015.

Muhlhaus, H.-B., Sakaguchi, H., and Hobbs, B. E.: Evolution of three-dimensional folds for a non-Newtonian plate in a viscous medium, P. R. Soc. A, 454, 3121-3143, https://doi.org/10.1098/rspa.1998.0294, 1998.

O'Dea, M. G. and Lister, G. S.: The role of ductility contrast and basement architecture in the structural evolution of the Crystal Creek block, Mount Isa Inlier, NW Queensland, Australia, J. Struct. Geol., 17, 949-960, https://doi.org/10.1016/01918141(94)00117-I, 1995. 
Porada, H. and Berhorst, V.: Towards a new understanding of the Neoproterozoic-Early Palaeozoic Lufilian and northern Zambezi Belts in Zambia and the Democratic Republic of Congo, J. Afr. Earth Sci., 30, 727-771, https://doi.org/10.1016/S08995362(00)00049-X, 2000.

Porada, H. and Druschel, G.: Evidence for participation of microbial mats in the deposition of the siliciclastic "ore formation" in the Copperbelt of Zambia, J. Afr. Earth Sci., 58, 427-444, https://doi.org/10.1016/j.jafrearsci.2010.04.006, 2010.

Potma, W. A. and Betts, P. G.: Extension-related structures in the Mitakoodi Culmination: Implications for the nature and timing of extension, and effect on later shortening in the eastern Mt Isa Inlier, Aust. J. Earth Sci., 53, 55-67, https://doi.org/10.1080/08120090500432421, 2006.

Price, N. J. and Cosgrove, J. W.: Analysis of Geological Structures, 502 pp., Cambridge University Press, Cambridge, UK, 1990.

Rainaud, C., Master, S., Armstrong, R. A., and Robb, L. J.: Geochronology and nature of the Palaeoproterozoic basement in the Central African Copperbelt (Zambia and the Democratic Republic of Congo), with regional implications, J. Afr. Earth Sci., 42, 1-31, https://doi.org/10.1016/j.jafrearsci.2005.08.006, 2005a.

Rainaud, C., Master, S., Armstrong, R. A., Phillips, D., and Robb, L. J.: Monazite U-Pb dating and 40Ar-39Ar thermochronology of metamorphic events in the Central African Copperbelt during the Pan-African Lufilian Orogeny, J. Afr. Earth Sci., 42, 183199, 2005b.

Ramsay, J. G.: Folding and Fracturing of Rocks, McGraw-Hill, Inc., 562 pp., 1967.

Schmalholz, S. M. and Schmid, D. W.: Folding in power-law viscous multi-layers, Philos. T. Roy. Soc. A, 370, 1798-826, https://doi.org/10.1098/rsta.2011.0421, 2012.

Schmid, D. W., Dabrowski, M., and Krotkiewski, M.: Evolution of large amplitude 3D fold patterns: A FEM study, Phys. Earth Planet. In., 171, 400-408, https://doi.org/10.1016/j.pepi.2008.08.007, 2008.

Schwellnus, J. E. G.: Bancroft-Nchanga area, in: The geology of the northern Rhodesian Copperbelt, edited by: Mendelsohn, F., Macdonald, London, 214-233, 1961.

Selley, D., Broughton, D., Scott, R. J., Hitzman, M., Bull, S. W., Large, R. R., McGoldrick, P. J., Croaker, M., Pollington, N., and Barra, F.: A new look at the geology of the Zambian Copperbelt, Econ. Geol., 100, 965-1000, 2005.

Sillitoe, R. H., Perelló, J., Creaser, R. A., Wilton, J., Wilson, A. J., and Dawborn, T.: Age of the Zambian Copperbelt, Miner. Deposita, 52, 1245-1268, 2017.

Tanner, G. P. W.: The flexural-slip mechanism, J. Struct. Geol., 11, 635-655, https://doi.org/10.1016/0191-8141(89)90001-1, 1989.

Tavani, S., Storti, F., Salvini, F., and Toscano, C.: Stratigraphic versus structural control on the deformation pattern associated with the evolution of the Mt. Catria anticline, Italy, J. Struct. Geol., 30, 664-681, https://doi.org/10.1016/j.jsg.2008.01.011, 2008.

Tembo, F., Kampunzu, A. B., and Porada, H.: Tholeiitic magmatism associated with continental rifting in the Lufilian Fold Belt of Zambia, J. Afr. Earth Sci., 28, 403-425, https://doi.org/10.1016/s0899-5362(99)00012-3, 1999.

Thieme, J. G. and Johnson, R. L.: Geological map of the Republic of Zambia, Scale 1: 1000 000, Geol. Surv. Zambia, Lusaka, Zambia, 1981.
Torremans, K., Gauquie, J., Boyce, A. J., Barrie, C. D., Dewaele, S., Sikazwe, O., and Muchez, P.: Remobilisation features and structural control on ore grade distribution at the Konkola stratiform $\mathrm{Cu}-\mathrm{Co}$ ore deposit, Zambia, J. Afr. Earth Sci., 79, 10-23, https://doi.org/10.1016/j.jafrearsci.2012.10.005, 2013.

Torremans, K., Muchez, P., and Sintubin, M.: Mechanisms of flexural flow folding of competent single-layers as evidenced by folded fibrous dolomite veins, J. Struct. Geol., 69, 75-90, https://doi.org/10.1016/j.jsg.2014.10.002, 2014.

Treagus, J. E. and Treagus, S. H.: Folds and the strain ellipsoid: a general model, J. Struct. Geol., 3, 1-17, https://doi.org/10.1016/0191-8141(81)90052-3, 1981.

Treagus, S. H. and Fletcher, R. C.: Controls of folding on different scales in multilayered rocks, J. Struct. Geol., 31, 1340-1349, https://doi.org/10.1016/j.jsg.2009.07.009, 2009.

Turlin, F., Eglinger, A., Vanderhaeghe, O., André-Mayer, A.-S., Poujol, M., Mercadier, J., and Bartlett, R.: Synmetamorphic $\mathrm{Cu}$ remobilization during the Pan-African orogeny: Microstructural, petrological and geochronological data on the kyanitemicaschists hosting the $\mathrm{Cu}(-\mathrm{U})$ Lumwana deposit in the Western Zambian Copperbelt of the Lufilian belt, Ore Geol. Rev., 75 , 52-75, https://doi.org/10.1016/j.oregeorev.2015.11.022, 2016.

Van Noten, K., Muchez, P., and Sintubin, M.: Stress-state evolution of the brittle upper crust during compressional tectonic inversion as defined by successive quartz vein types (HighArdenne slate belt, Germany), J. Geol. Soc., 168, 407-422, https://doi.org/10.1144/0016-76492010-112, 2011.

Van Noten, K., Van Baelen, H., and Sintubin, M.: The complexity of 3D stress-state changes during compressional tectonic inversion at the onset of orogeny, Geol. Soc. Spec. Publ., 367, 51-69, https://doi.org/10.1144/SP367.5, 2012.

Van Wilderode, J., Debruyne, D., Torremans, K., Elburg, M. A., Vanhaecke, F., Muchez, P., Balcaen, L., Elburg, M. A., Vanhaecke, F., and Muchez, P.: Metal sources for the Nkana and Konkola stratiform $\mathrm{Cu}-\mathrm{Co}$ deposits (Zambian Copperbelt): Insights from $\mathrm{Sr}$ and $\mathrm{Nd}$ isotope ratios, Ore Geol. Rev., 67, 127138, https://doi.org/10.1016/j.oregeorev.2014.11.011, 2015.

Winfield, O. and Robinson, I. C.: The structures of Chibuluma mine, in: Stratiform Copper Deposits in Africa, Association of African Geological Surveys, edited by: Lombard, J. and Nicolini, P., Association of African Geological Surveys, Paris, 192-202, 1963.

Woodcock, N. H. and Naylor, M. A.: Randomness testing in three-dimensional orientation data, J. Struct. Geol., 5, 539-548, https://doi.org/10.1016/0191-8141(83)90058-5, 1983.

Zientek, M. L., Bliss, J. D., Broughton, D. W., Christie, M., Denning, P. D., Hayes, T. S., Hitzman, M. W., Horton, J. D., FrostKillian, S., Douglas, J. J., Master, S., Parks, H. L., Taylor, C. D., Wilson, A. B., Wintzer, N. E., and Woodhead, J.: Sedimenthosted stratabound copper assessment of the Neoproterozoic Roan Group, Central African Copperbelt, Katanga basin, Democratic Republic of the Congo and Zambia, in: U.S. Geological Survey Scientific Investigations Report 2010-5090-T, 162 pp., https://doi.org/10.3133/sir20105090T, U.S. Geological Survey, Reston, VA, USA, 2010. 